University of Nebraska - Lincoln

DigitalCommons@University of Nebraska - Lincoln

Papers in the Earth and Atmospheric Sciences

Earth and Atmospheric Sciences, Department

2008

\title{
The Geology of Ukhaa Tolgod (Djadokhta Formation, Upper Cretaceous, Nemegt Basin, Mongolia)
}

\author{
Lowell Dingus \\ American Museum of Natural History, Idingus@earthlink.net \\ David B. Loope \\ University of Nebraska, Lincoln, dloope1@unl.edu \\ Demberlyin Dashzeveg \\ Geological Institute of the Mongolian Academy of Sciences \\ Carl C. Swisher III \\ Rutgers University \\ Chuluun Minjin \\ Mongolian Technical University \\ See next page for additional authors
}

Follow this and additional works at: https://digitalcommons.unl.edu/geosciencefacpub

Part of the Earth Sciences Commons

Dingus, Lowell; Loope, David B.; Dashzeveg, Demberlyin; Swisher, Carl C. III; Minjin, Chuluun; Novacek, Michael J.; and Norell, Mark A., "The Geology of Ukhaa Tolgod (Djadokhta Formation, Upper Cretaceous, Nemegt Basin, Mongolia)" (2008). Papers in the Earth and Atmospheric Sciences. 217.

https://digitalcommons.unl.edu/geosciencefacpub/217

This Article is brought to you for free and open access by the Earth and Atmospheric Sciences, Department of at DigitalCommons@University of Nebraska - Lincoln. It has been accepted for inclusion in Papers in the Earth and Atmospheric Sciences by an authorized administrator of DigitalCommons@University of Nebraska - Lincoln. 


\section{Authors}

Lowell Dingus, David B. Loope, Demberlyin Dashzeveg, Carl C. Swisher III, Chuluun Minjin, Michael J. Novacek, and Mark A. Norell 


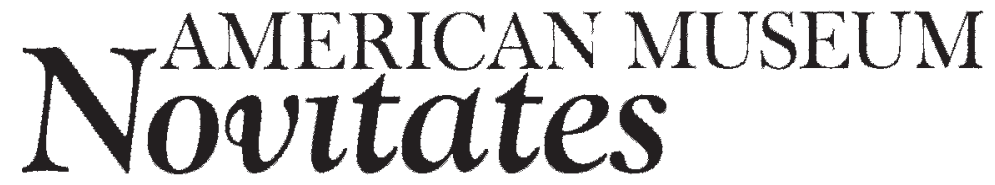

PUBLISHED BY THE AMERICAN MUSEUM OF NATURAL HISTORY CENTRAL PARK WEST AT 79TH STREET, NEW YORK, NY 10024 Number 3616, 40 pp., 26 figures, 1 table

June 16, 2008

\title{
The Geology of Ukhaa Tolgod (Djadokhta Formation, Upper Cretaceous, Nemegt Basin, Mongolia)
}

\author{
LOWELL DINGUS, ${ }^{1}$ DAVID B. LOOPE, ${ }^{2}$ DEMBERLYIN DASHZEVEG ${ }^{3}$ \\ CARL C. SWISHER III, ${ }^{4}$ CHULUUN MINJIN, ${ }^{5}$ MICHAEL J. NOVACEK, ${ }^{1}$ AND \\ MARK A. NORELL ${ }^{1}$
}

\begin{abstract}
The lithostratigrahy and sedimentology of the fossiliferous Upper Cretaceous strata exposed in the Gobi Desert of Mongolia at Ukhaa Tolgod are described and mapped on aerial photos. Topographic features are also mapped by plane table and alidade.

Five lithologic and sedimentologic facies are described: E-1, distinctly cross-stratified sandstone with fine structure, interpreted to represent eolian dune deposits; E-2, vaguely bedded sandstone with cross-stratified concretionary sheets, interpreted to represent eolian dune deposits modified by diagenetic formation of slope-parallel concretionary sheets of pedogenic calcite; S, structureless sandstone lacking concretions or cross-strata, interpreted to represent sandslide deposits generated by mass wasting along the lee slopes; $\mathrm{C}$, conglomerate interpreted to represent basin-margin conglomerates washed into the dune field from adjacent topographic highs; and $\mathrm{M}$, mudstone and siltstone interpreted to represent interdune deposition in ephemeral ponds and lakes. Facies E-2 and $\mathrm{S}$ have not been reported previously. Eleven stratigraphic sections at various localities within the Ukhaa Tolgod drainage basin are documented. The exposed composite section consists of about $75 \mathrm{~m}$ of pale orange sandstones, greenish-brown conglomerates, and brown siltstones that are products of an arid environment. Four schematic cross sections are documented to illustrate the lateral relationships among the five facies.
\end{abstract}

\footnotetext{
${ }^{1}$ Division of Paleontology, American Museum of Natural History (ldingus@earthlink.net).

${ }^{2}$ Department of Geosciences, University of Nebraska Lincoln, Nebraska 68588-0340.

${ }^{3}$ Geological Institute of the Mongolian Academy of Sciences, Peace Street 63, Ulaanbaatar-51, Mongolia.

${ }^{4}$ Department of Geology, Rutgers University, 610 Taylor Road, Piscataway, NJ 08854.

${ }^{5}$ Department of Geology and Mineralogy, P.O. Box 46/225, Mongolian Technical University, Ulaanbaatar, Mongolia.
} 
In the Ukhaa Tolgod area, the beds dip about $2.5^{\circ}$ to the south, away from the nearby Gilbent Range. This structural attitude is interpreted to be related to the uplift of the Gilbent block along normal faults exposed at the base of the range.

The dune-derived sandslides of Facies S contain a rich skeletal fauna of Late Cretaceous dinosaurs, mammals, and lizards. Essentially, all the skeletal remains collected at Ukhaa Tolgod come from Facies S. Facies E-1 does contain numerous, concave-up depressions in the cross-strata interpreted as vertebrate tracks. Facies E-2 contains abundant cylindrical structures interpreted as burrows.

The strata at Ukhaa Tolgod are referred to the Djadokhta Formation. As seen in the Bayn Dzak Member at Bayn Dzak, facies E-1, E-2, S, and M dominate the lower part of the section at Ukhaa Tolgod, with prominent beds of Facies $\mathrm{C}$ exposed near the top. Accordingly, the exposures at Ukhaa Tolgod are referred to the Bayn Dzak Member of the Djadokhta Formation. Classic exposures of the Barun Goyot Formation at Khulsan differ in having units of flat-bedded sandstone intercalated with beds of Facies $\mathrm{S}$ near the top of the section.

To date, over 1,000 vertebrate skulls and skeletons have been collected from Facies S. Most are preserved as float contained in small calcareous nodules; however, some were found in situ. Many specimens represent either fairly complete skulls or skulls with articulated or associated postcranial skeletons. Based on faunal similarities between Bayn Dzak and Ukhaa Tolgod, the fauna at Ukhaa Tolgod is interpreted to reflect a Campanian age. The rich assemblage of fossils makes Ukhaa Tolgod one of the richest Late Cretaceous vertebrate fossil localities in the world, and the fossils provide unique insights into evolutionary developments of mammals, lizards, and dinosaurs, including birds, less than 10 my before the terminal Cretaceous extinction event.

\section{INTRODUCTION}

Dashzeveg et al. (2005) provide a summary of research carried out in the classic exposures of the Djadokhta Formation at Bayn Dzak (= Bayan Zag of Benton, 2000) in the southern Ulan Nur Basin of Mongolia's Gobi Desert. The same authors divide the Djadokhta Formation into a lower Bayn Dzak Member exposed at Bayn Dzak and an upper Tugrugyin Member exposed at Tugrugyin Shireh (= Tögrögiin Shiree of Benton, 2000). Here, we focus on previous work done in the Nemegt Basin, which lies to the south of the Ulan Nur Basin near Mongolia's border with the People's Republic of China.

Expeditions by the Soviet Academy of Sciences between 1946 and 1949 extended paleontologic exploration in Mongolia southward into the Upper Cretaceous Nemegt Formation of the Nemegt Basin, where they discovered several Latest Cretaceous taxa including Tarbosaurus baatar and Saurolophus angustrirostris (Efremov, 1949, 1954; Maleev, 1952, 1954).

Between 1963 and 1971, the PolishMongolian Palaeontological Expeditions discovered rich, Late Cretaceous fossil localities in the Barun Goyot Formation (= Baruungoyot in Benton, 2000) of the Nemegt Basin to the southwest of Bayn Dzak, as well as the red beds of Khermeen Tsav (= Hermiin Tsav of Benton, 2000) in the western Nemegt Basin (Kielan-Jaworowska and Dovchin, 1969; KielanJaworowska and Barsbold, 1972). The expeditions assembled impressive collections of Cretaceous mammals (Kielan-Jaworowska, 1969, 1970, 1974, 1975, 1984; see also KielanJaworowska et al., 2000; Kielan-Jaworowska et al., 2003 and 2004, for summaries). The rich fauna of dinosaurs from the Djadokhta and Barun Goyot Formations has been described by Maryańska and Osmólska (e.g., Maryańska, 1971; Maryańska and Osmólska, 1975; Osmólska, 1972, 1976, 1980, 1993). Lizards from these formations are discussed in (e.g., Sulimski, 1975; Borsuk-Bialynicka 1984, 1991a, 1991b; see also Alifanov, 2000, as well as Gao and Norell, 2000, for other faunal summaries).

Soviet-Mongolian (subsequently RussianMongolian) expeditions were conducted in Mongolia beginning in 1970, and continued until recently, as reviewed by Kurochkin and Barsbold (2000).

From 1992 to the present, the JapanMongolia Joint Paleontological Expedition (JMJPE) has conducted extensive field seasons throughout the Gobi Desert. Recent accounts of their activities are presented in Ishii et al. (2000, 2004). 
In 1991, following a brief reconnaissance trip in 1990, the Mongolian Academy of Sciences-American Museum of Natural History Expedition (MAE) began field investigations based on the Agreement on Scientific Cooperation between those two institutions. In 1993, 70 years after Andrews' Central Asiatic Expedition discovered the first welldocumented clutches of dinosaur eggs, the first-known skeletons of the dinosaurs Protoceratops and Velociraptor, and the first well-preserved skulls of Late Cretaceous mammals at Bayn Dzak (Osborn, 1924; Simpson, 1925; Gregory and Simpson, 1926; Berkey and Morris, 1927; Andrews, 1932; Morris, 1936), members of the MAE discovered a new fossil locality in the Nemegt Basin called Ukhaa Tolgod, which means "Brown Hills" (Dashzeveg et al., 1995). This locality has yielded an unmatched abundance of wellpreserved vertebrate fossils, including the highest concentration of mammalian skulls and skeletons from any known Mesozoic site. More than 100 skeletons of theropod, ankylosaurian, and protoceratopsian dinosaurs have been identified, including specimens of Late Cretaceous birds (Chiappe et al., 1998, 2001, 2002; Schweitzer et al., 1999; Norell and Clarke, 2001; Suzuki et al., 2001), oviraptorid dinosaurs (Clark et al., 2001), including a specimen positioned on top of a nest of eggs in brooding posture (Norell et al., 1995; Clark et al., 1999), a partial ornithomimid braincase (Makovicky and Norell, 1998) and the first known embryo of a theropod (Norell et al., 1994). Johnston et al. (1996) discussed alleged vertebrate eggs that they identified as fossilized pupal chambers. Recent publications regarding the mammalian fauna include Horovitz (2000); Kielan-Jaworowska (1998); Kielan-Jaworowska et al. (2000); Novacek et al. (1997); Rougier et al. (1996, 1997, 1998); Wible and Rougier (2000), and Wible et al. (2004). In all, over 1,000 skulls, many with associated skeletons, of mammals, lizards, and dinosaurs have been identified. In relation to other Mesozoic localities, the concentration and diversity of mammals, lizards, and dinosaurs are unusually high.

As a result of these paleontological expeditions, an extensive body of literature has been published regarding the geology of the
Djadokhta and Baurn Goyot formations (Gradziński, 1970; Lefeld, 1965, 1971; Gradziński and Jerzykiewicz, 1972, 1974a, 1974b; Jerzykiewicz, 1998, 2000; Jerzykiewicz and Russell, 1991; Jerzykiewicz et al. 1993a, 1993b; and Shuvalov, 2000).

Large-scale cross-bedded strata of the Djadokhta have been previously interpreted as both deltaic (Tverdochlebov and Tsybin, 1974) and eolian (Gradziński and Jerzykiewicz, 1974b; Eberth, 1993; Jerzykiewicz et al., 1993a, 1993b; Fastovsky et al., 1997). Most recent interpretations have favored an eolian origin for these large-scale cross-stratified sandstones (Eberth, 1993; Fastovsky et al., 1997; Loope et al., 1998). However, the skeletally fossiliferous units at Ukhaa Tolgod are not cross-stratified (Loope et al., 1998). We recognize three different sandstone facies at Ukhaa Tolgod. Two are eolian, containing distinctly to vaguely cross-stratified sandstone. These accumulated during relatively rapid and slow migration of large bedforms. The third and only skeletally fossiliferous sandstone facies is structureless and often contains lenses of granules and pebbles as well as floating cobbles. It has previously been suggested that these rocks also resulted from very rapid eolian deposition (Eberth, 1993). However, Loope et al. (1998, 1999 ) interpret this facies to represent mass flows that buried lee slopes and (with intermixed fluvial deposits) filled interdunes during mesic intervals when the dunefield was stabilized.

Within the distinctly cross-stratified eolian sandstone are numerous deformed zones that represent vertical cross sections of dinosaur tracks - the first such tracks known from the Late Cretaceous rocks of the Gobi Desert and clear evidence that dinosaurs traversed actively migrating dunes (Loope et al., 1998). Bioturbation and accumulation of clay and pedogenic carbonates in the fossiliferous eolian facies support the sandslide interpretation of the laterally adjacent structureless sandstones. Together, these lines of evidence indicate that the large dunes of the Late Cretaceous landscape were stabilized for long periods of time, and, when active, migrated by deposition of wind-ripple strata and thin grain flows (Hunter, 1977). 
Here, in addition to documenting and describing the strata and facies exposed at Ukhaa Tolgod, we evaluate the question of whether these strata should be assigned to the Djadokhta or Barun Goyot Formation and discuss the age of the vertebrate fossils from the site.

\section{MODERN TOPOGRAPHIC FEATURES AND MAJOR FOSSIL LOCALITIES}

Ukhaa Tolgod lies about $650 \mathrm{~km}$ southwest of Ulaanbaatar in the Nemegt Basin of Mongolia, a post-Oligocene tectonic depression controlled by normal faulting (Gradziński et al., 1977). The Gilbent Uul forms the northern edge of the Nemegt Basin in the area near Ukhaa Tolgod.

Ukhaa Tolgod means "brown hills" in Mongolian, and the field area is marked by a series of reddish brown bluffs, buttes, and escarpments. Overall, the collecting area is about $2.2 \mathrm{~km}$ across and follows the bluffs of a northeast-southwest trending drainage basin eroded into the southward-inclined alluvial apron of the Gilbent Uul. It is located at about $43^{\circ} 32^{\prime} \mathrm{N}$ latitude and $101^{\circ} 34^{\prime} \mathrm{E}$ longitude, and about $1500 \mathrm{~m}$ above sea level.

One of us (C. M.) constructed a physiographic map of the Ukhaa Tolgod area using a plane table and alidade (map 1), which documents the locations of eight separate collecting areas in the northern half of the Ukhaa Tolgod drainage basin: Ankylosaur Flats, Sphinx, Sugar Mountain, Death Row, Camel Humps, Xanadu, First Strike, and Zofia's Hill. The facies maps (maps 2-6) further document the location of these eight localities, as well as four additional ones in the southern half of the Ukhaa Tolgod drainage basin: Romeo and Juliet, Delta Force, Granger Hill, and Downlap Hill.

\section{Lithologic Units and Sedimentologic Facies}

The strata exposed at Ukhaa Tolgod consist of five distinct lithologic and sedimentologic facies, all nonmarine sandstones, siltstones, and conglomerates. Three sandstone facies dominate. Conglomerate is relatively rare, while mudstones and siltstones are thin and laterally restricted.

\section{EOLIAN Facies}

Distinctly Cross-stratified Sandstone with Fine Structure (Facies E-1)

DESCRIPTION: This facies is composed predominantly of moderate reddish orange (10R $6 / 6)$ to pale red (10R 6/2) to moderate orange pink (10R 7/4), fine- to coarse-grained sand that was deposited in distinct laminae that consistently dip 25 degrees to the northeast (fig. 1). Nearly all of the distinct cross-strata present at Ukhaa Tolgod lie within one laterally discontinuous set that is typically about $12 \mathrm{~m}$ thick. Small-diameter burrows (4$10 \mathrm{~mm}$ ) and occasional rhizoliths ( $\leq 2 \mathrm{~mm}$ in diameter) are present within these cross-strata. Concave up folds that are circular to oval in plan and range from $10-50 \mathrm{~cm}$ across are common along certain cross-strata (fig. 2). Sharp contacts separate the folded from the overlying, unfolded strata, and coarse-grained sediment typically fills the central shaft at the core of each fold. Skeletal fossil remains are not present. On the facies maps (maps 2-6), this facies is represented by $\mathrm{Ke}$.

INTERPRETATION: Large-scale cross-strata in the Late Cretaceous redbeds of the Gobi have been interpreted as eolian by Gradzinski and Jerzykiewicz (1974b) at Bayn Dzak, Jerzykiewicz et al. (1993a, 1993b) and Eberth (1993) at Bayan Mandahu in Inner Mongolia, and Fastovsky et al. (1997) at Tugrugyin Shireh, and we concur with their interpretation (Loope et al., 1998, 1999). Some earlier interpretations suggested a deltaic origin for these cross-strata (Tverdochlebov and Tsybin, 1974); however, that interpretation does not conform well with the following evidence.

By making direct observations during sandstorms within the dunefields of coastal Oregon and Texas, Hunter (1977) demonstrated that distinct, relatively thin laminae and beds are produced during the migration of eolian dunes and ripples. The laminae produced by climbing wind ripples are inverse graded. Deposits of extensive Mesozoic and Paleozoic sand seas of the western United States (Kocurek, 1988) are clearly composed of the characteristic bedding types described by Hunter (1977). Such inverse-graded ripple laminations are present but usually poorly preserved at Ukhaa Tolgod. They are clearly present and well 


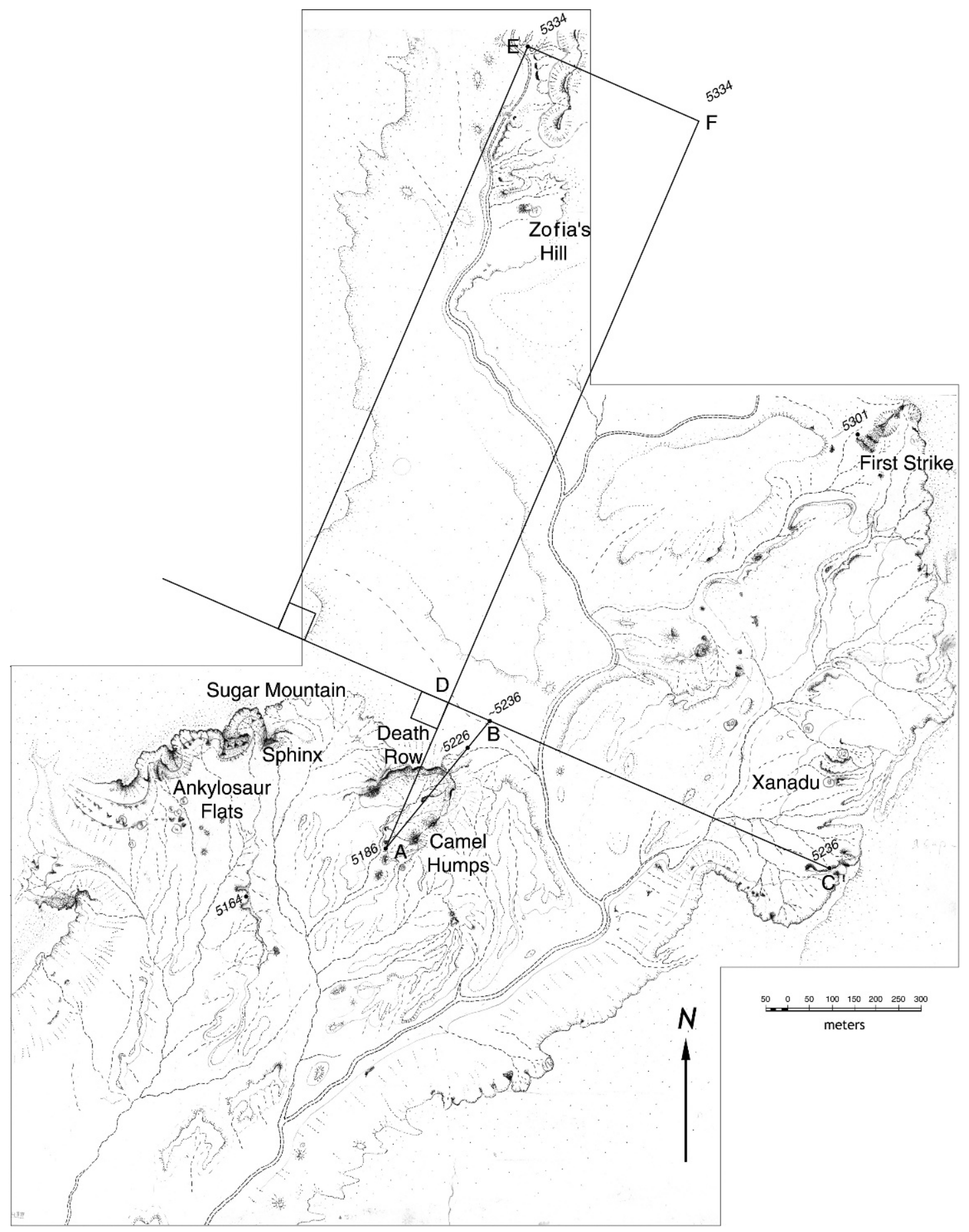

Map 1. Physiographic map of Ukhaa Tolgod. Major physiographic features and fossil localities are labeled. (Construction lines and boxes relate to discussion found in Calculation of Local Dip.) 


\section{Facies}

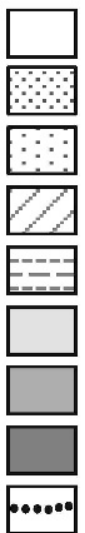

Qp Quaternary pediment

Qc Quaternary colluvium

Kc Cretaceous conglomerate

Kcs Cretaceous conglomerate and sandstone

$\mathrm{Ke}$ Cretaceous cross-bedded eolian sandstone

$\mathrm{Km}$ Cretaceous mudstone and siltstone

Ks Cretaceous structureless sandstone

Ksd Cretaceous structureless dune-derived sandstone

Ksf Cretaceous structureless flat-bedded sandstone

Kwp Cretaceous white caliche pebble unit

\section{- Streams}

- Facies contact

- - - Infered facies contact

$\frac{u}{\mathrm{D}}$ Fault

$\vdash \quad$ Strike and dip of cross-strata

$\Delta \quad$ Fossil locality

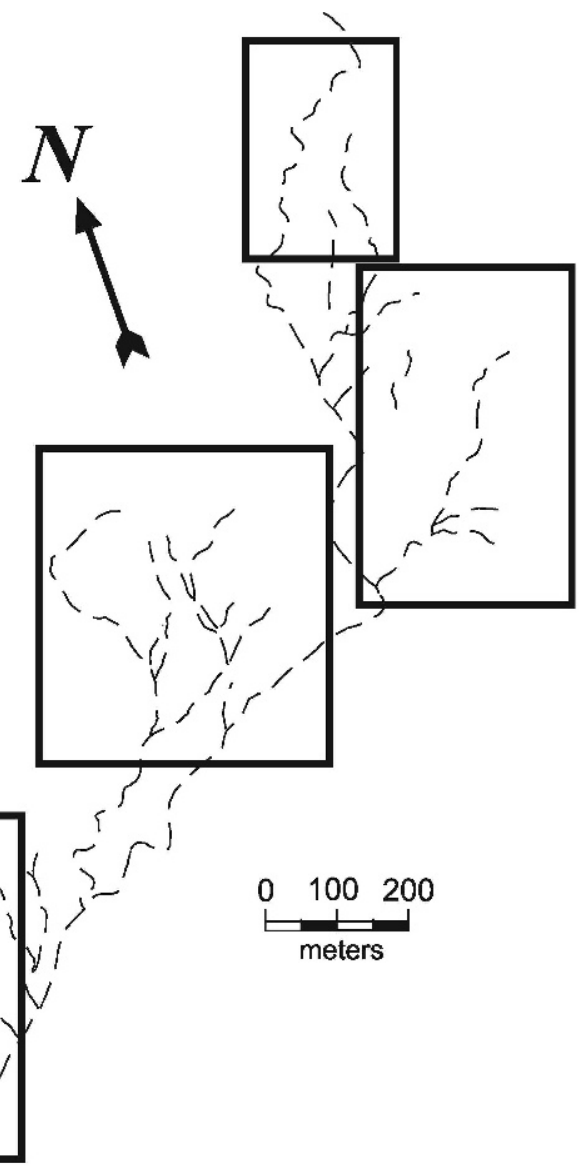

\section{Fossils}

$\begin{array}{ll}\text { A } & \text { ankylosaur } \\ \mathrm{D} & \text { dinosaur } \\ \mathrm{M} & \text { Mononykus } \\ \text { mamm } & \text { mammal } \\ \mathrm{N} & \text { nest } \\ \mathrm{O} & \text { Oviraptor } \\ \mathrm{P} & \text { protoceratopsian } \\ \text { Th } & \text { theropod } \\ \text { troo } & \text { Troodon } \\ \mathrm{T} & \text { turtle } \\ \mathrm{V} & \text { Velociraptor }\end{array}$

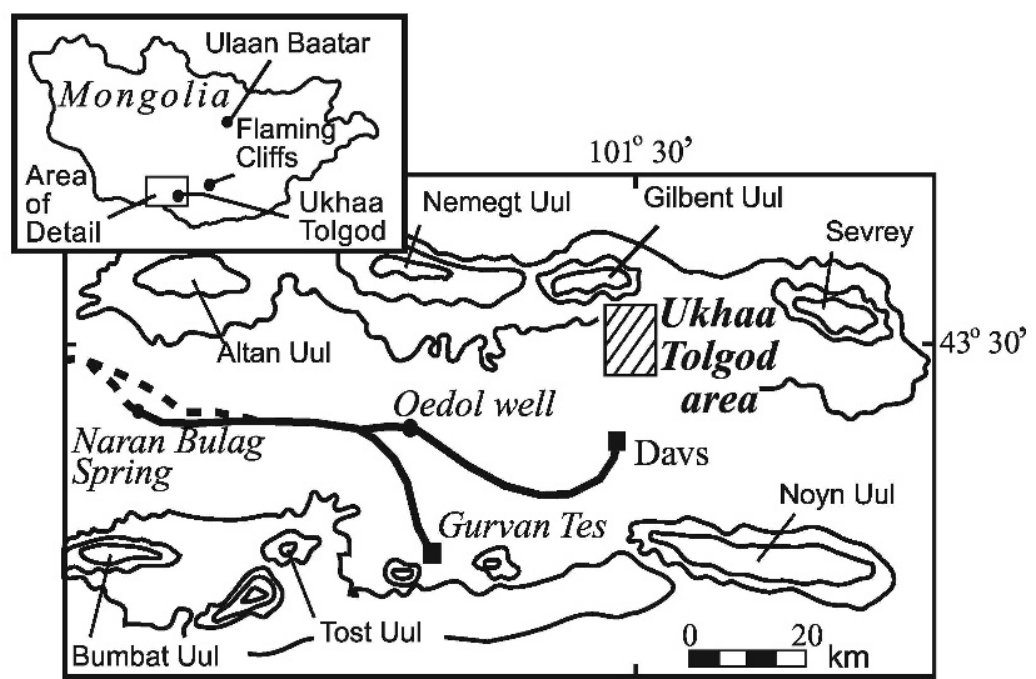

Map 2. Index for facies maps of units exposed at Ukhaa Tolgod. The legend applies to maps 3-6. Note: More generally, $\mathrm{M}=$ mononykine, $\mathrm{O}=$ oviraptorid, troo = troodontid, $\mathrm{V}=$ dromaeosaurid. 


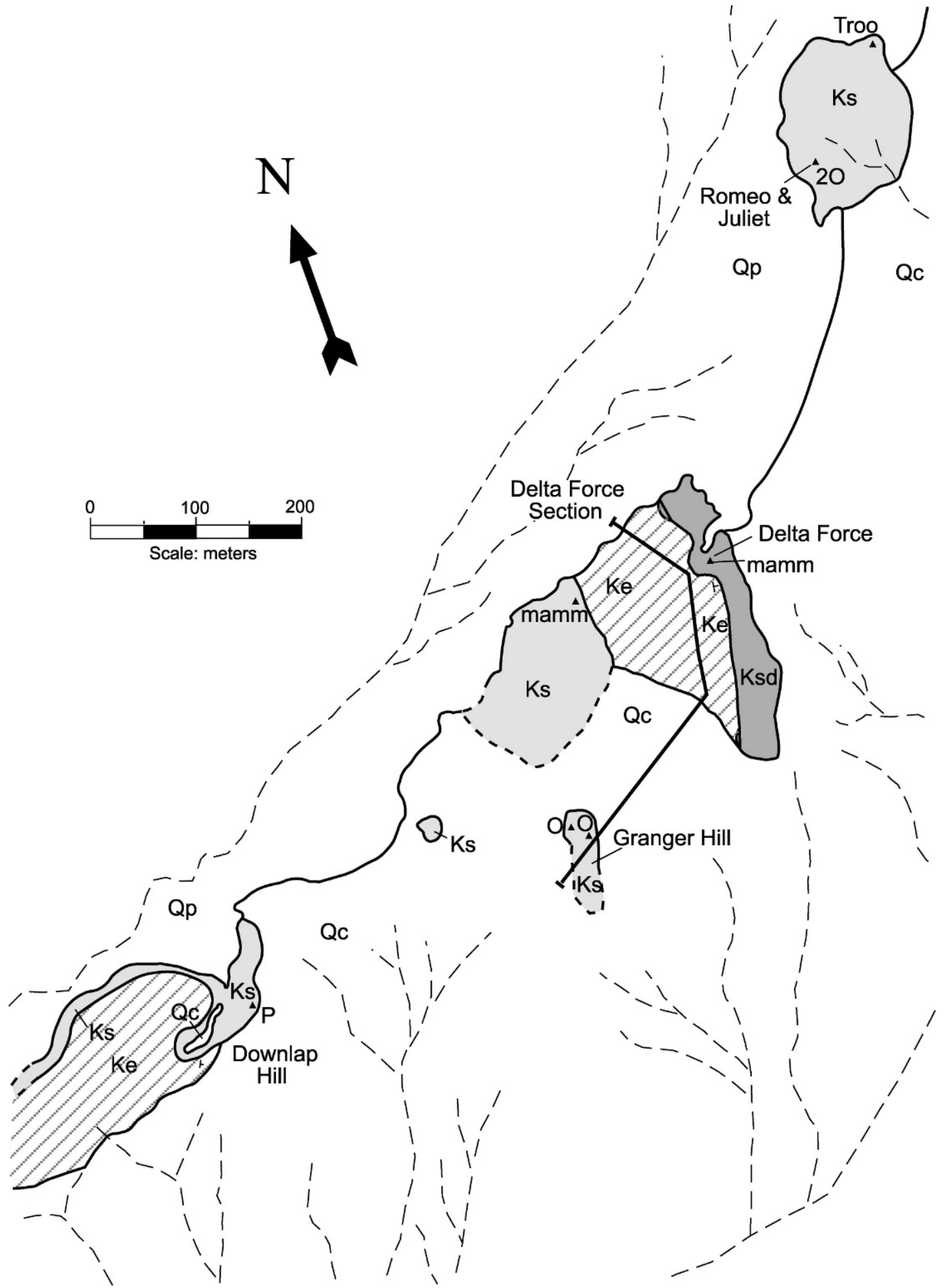

Map 3. Facies map for Downlap Hill, Granger Hill, Delta Force, and Romeo and Juliet (SW box on map 2). 


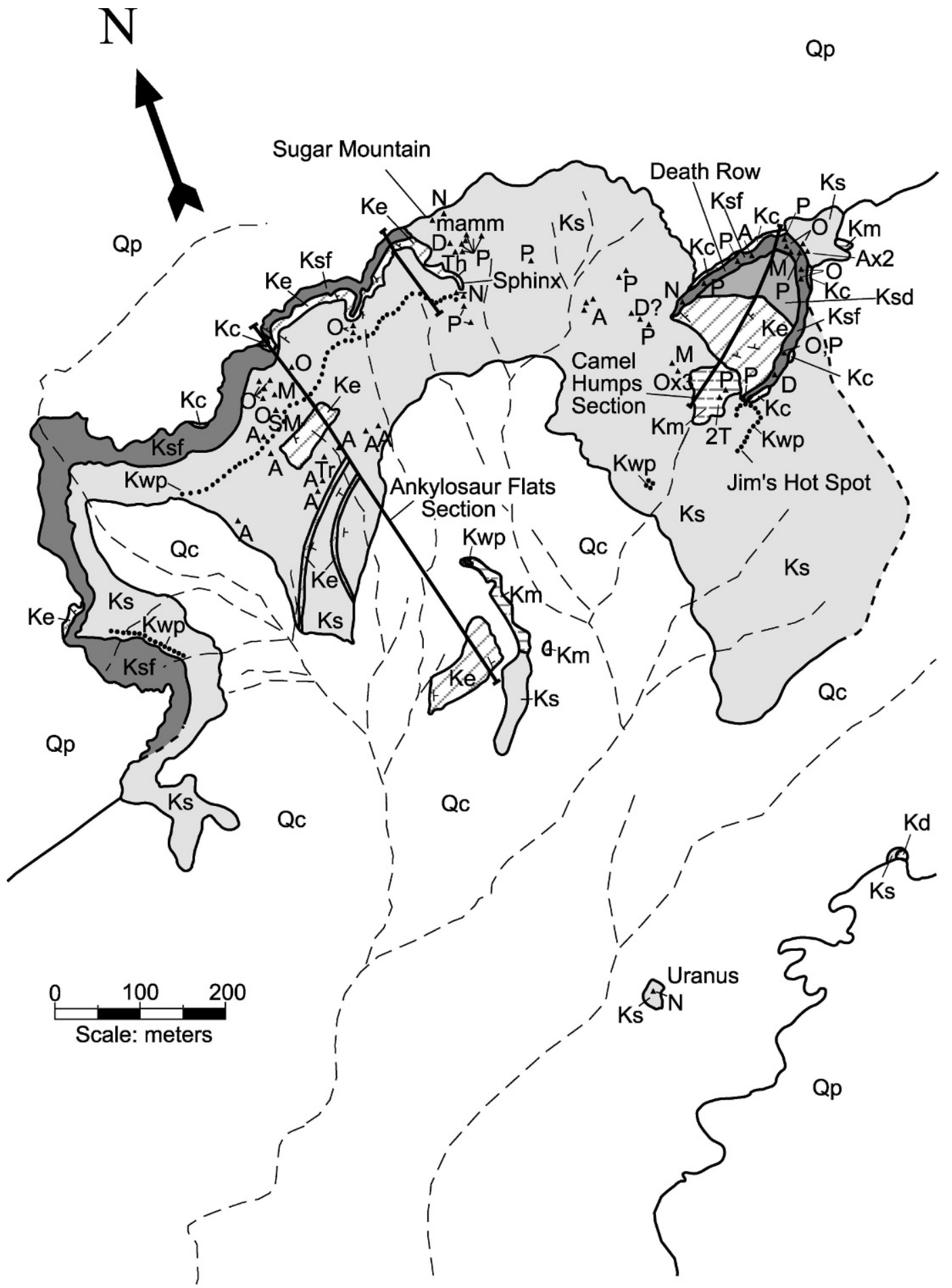

Map 4. Facies map for Ankylosaur Flats, Sphinx, Sugar Mountain, Camel Humps, and Death Row (W-central box on map 2). 


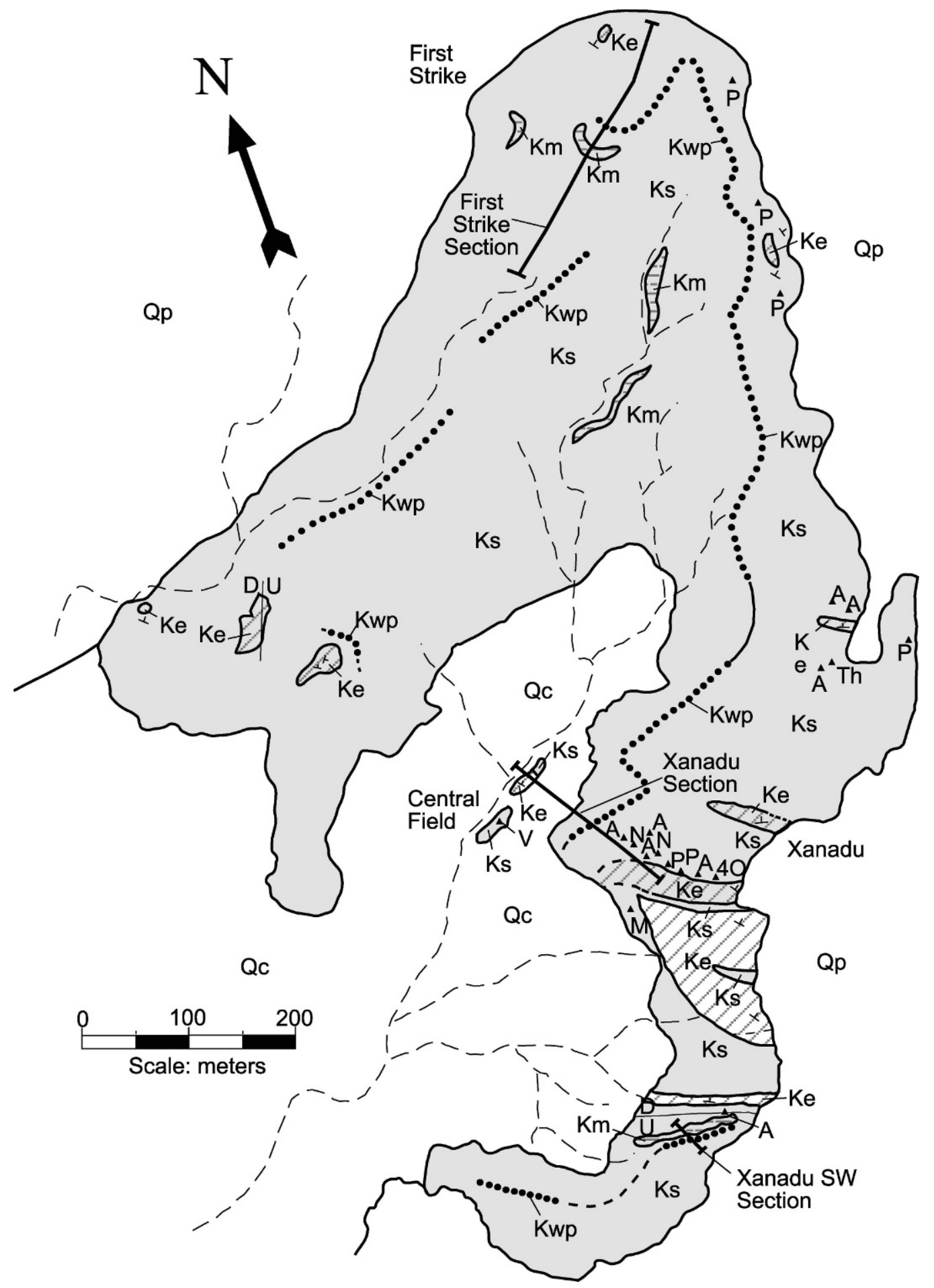

Map 5. Facies map for Xanadu SW, Xanadu, Central Field, and First Strike (E-central box on map 2). 
$\mathrm{N}$

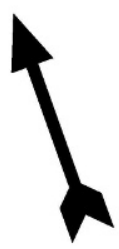

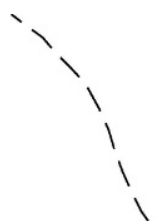

Zofia's

North

Qp

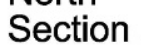

$\mathrm{Kcs}$

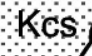

QC

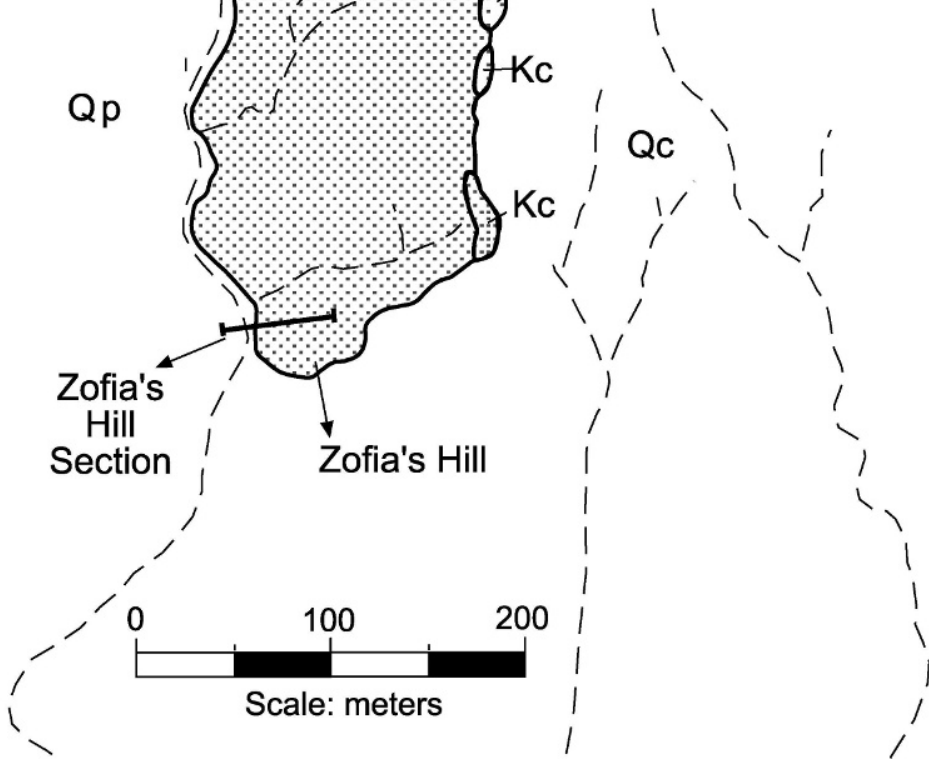

Map 6. Facies map for Zofia's Hill, Zofia's Middle, and Zofia's North (N-box on map 2). 


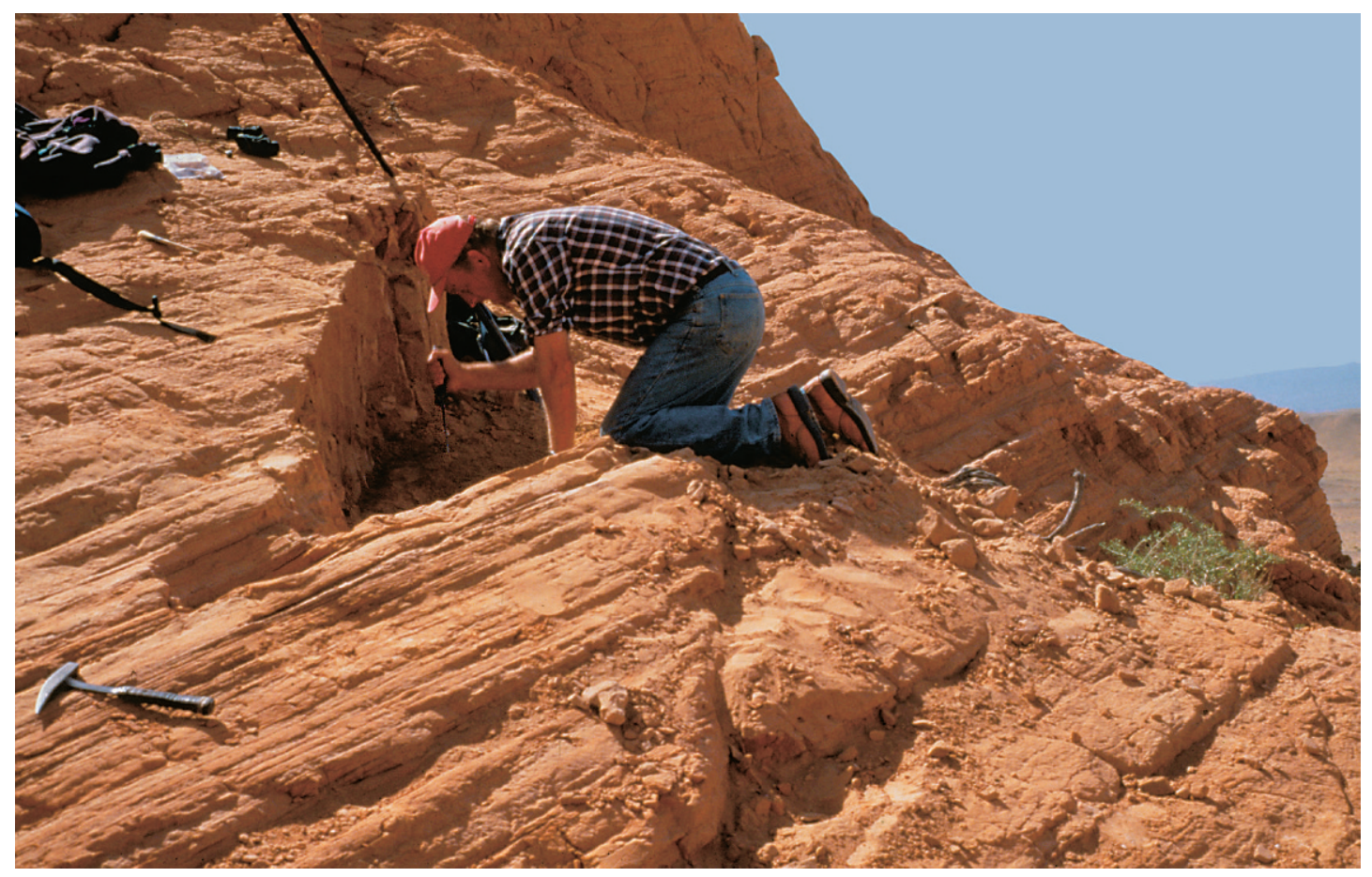

Fig. 1. Cross-stratified sandstone of Facies E-1, exposed near the base of the Sphinx, interpreted as eolian dune deposits.

developed in laterally equivalent exposures that crop out at Little Ukhaa-a locality about $10 \mathrm{~km}$ northwest of Ukhaa Tolgod proper (fig. 3). This distinctly cross-stratified facies (E-1) thus has sedimentary structures similar to those in Holocene dunes and wellstudied ancient eolian sandstones from the western U.S. and can thus be confidently interpreted as eolian. Although it has not yet proven possible to discern the velocity of paleowinds from eolian strata, if violent windstorms have left a sedimentary record in Mongolia and the western U.S., this distinctly stratified facies is that record (rather than the structureless sandstone facies discussed below).

Despite the presence of abundant fossil skeletons, dinosaur tracks have only recently been reported from the Djadokhta Formation (Loope et al., 1998). The scarcity of bedding plane exposures and the poor induration of the sandstones mitigate against recognition and preservation of tracks (Jerzykiewicz et al., 1993a, 1993b). Nevertheless, the thin-bedded, easily deformed sediments of this facies accumulated in an environment that was readily accessible to large animals. We confidently interpret the concave-up downfolds seen in vertical cross section in this facies as the tracks of large vertebrates (Loope et al., 1998). Like many tracks in the Jurassic Navajo Sandstone of southern Utah (Loope, 2006), these tracks are represented by smooth folds, and were probably emplaced in dry, cohesionless sand.

Vaguely Bedded Sandstone with Cross-stratified Concretionary Sheets (Facies E-2)

DESCRIPTION: Moderate reddish orange (10R 6/6) to moderate orange pink (10R 7/ 4 ), fine to coarse sand nearly devoid of visible depositional structures is cemented by tabular calcareous concretions that are $5-10 \mathrm{~cm}$ thick and dip 25 degrees to the northeast-parallel to the cross-strata of Facies E-1. In weathered horizontal exposures, the concretionary sheets weather into strong relief, defining straight to gently arcing ridges (fig. 4). The concretions delineate "sets" analogous to those of cross- 


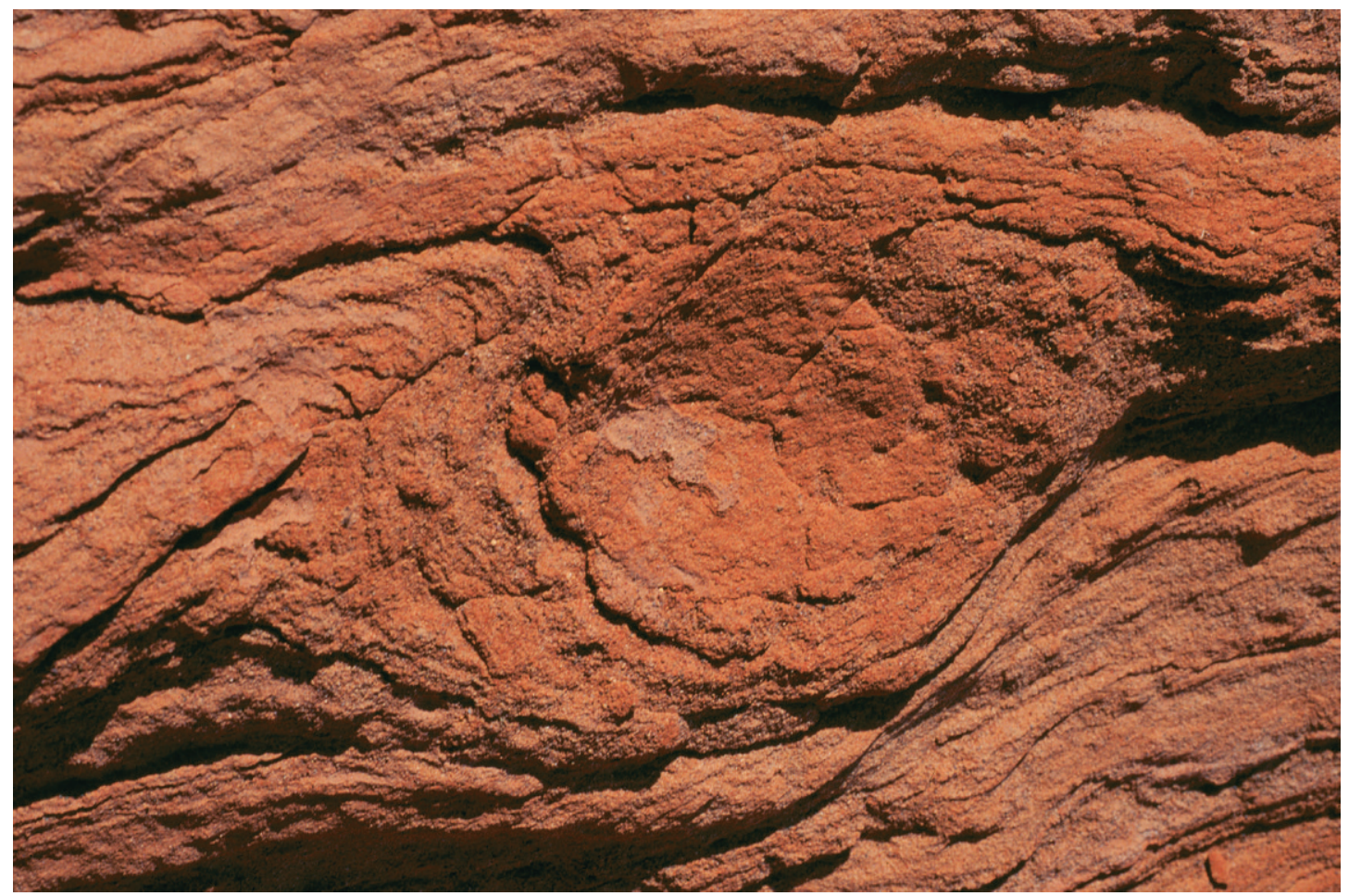

Fig. 2. Concave-up fold in cross-stratified sandstone of Facies E-1 interpreted as track of large vertebrate. Width of field of view is $30 \mathrm{~cm}$.

strata that are typically in excess of $10 \mathrm{~m}$ thick; the thickest set we measured near Delta Force, the base of which was not exposed, is $24.5 \mathrm{~m}$ thick.

Reddish yellow (YR 6/6), uncemented sand fills abundant simple, nonmeniscate burrows that cut lighter (7.5 YR7/4) concretions. In thin section, burrow margins are sharp, and calcite ranges from micrite to spar. Sand grains bear thin, often incomplete clay coats that are thickest in depressions in grain surfaces. Rhizoliths and other fossils are absent. On maps 2-6, this facies is represented by $\mathrm{Ke}$.

INTERPRETATION: Similarities in the texture and scale between the vague cross-strata of this facies and E-1 allow confident interpretation of Facies E-2 as eolian dune deposits. Although E-2 is nearly devoid of visible depositional structures, the postdepositional development of the concretionary sheets indicates preservation of a slope-parallel sedimentary fabric. At least two interpretations are possible: (1) First, distinct depositional structures were never present because plants acted as sediment baffles. According to Kocurek and Nielson (1986), plants interfere with the propagation of wind ripples, thereby preventing the development of distinctly laminated deposits typically produced by wind ripple lamination and climb. Unless plant cover is extremely uniform, however, baffling of saltating sand by plants should lead to growth of hummocks or plant mounds, the geometry of which is not reflected in the tabular nature of the concretionary sheets in E-2. (2) Alternatively, depositional structures were produced but were destroyed before burial. Although invertebrate burrows that were emplaced relatively deep in the sediment are present in great abundance, the retention of the crude fabric element that repeats at 10 $15 \mathrm{~cm}$ intervals suggests that the sediments were not deeply "stirred". Trampling by dinosaurs could have sufficiently mixed the surficial sediment to a depth of $10-15 \mathrm{~cm}$, 


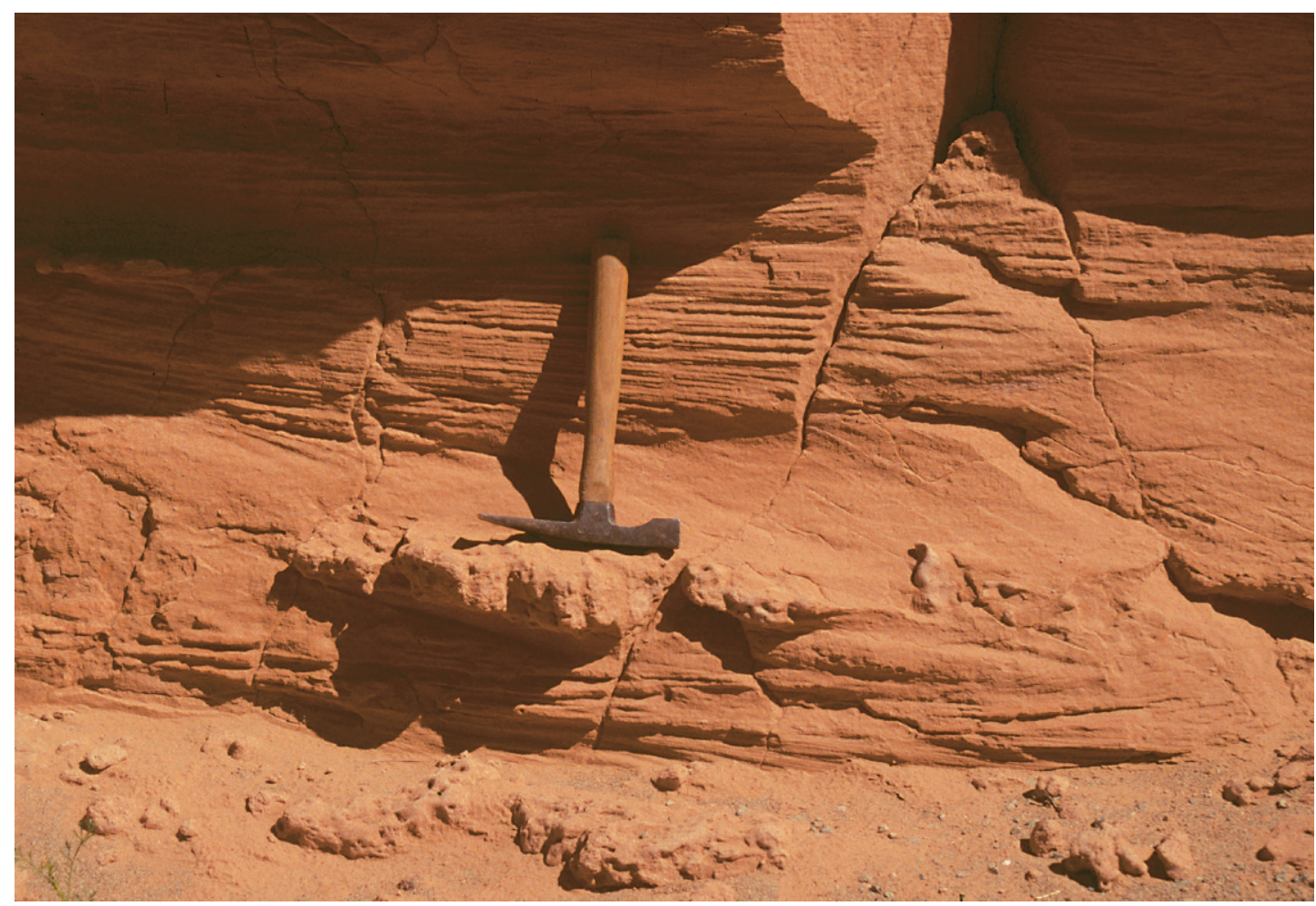

Fig. 3. Cross-stratified sandstone of Facies E-1, exposed at Little Ukhaa, containing inverse-graded ripple laminations, interpreted as migration of eolian dunes (far right) and ripples (center and left).

thereby preventing the preservation of physical structures but allowing the grain-size differences between different depositional packages to be preserved. Although our "dinoturbation" (Lockley and Gillette, 1989) hypothesis for E-2 is speculative, it is consistent with the facts that (1) dinosaur tracks are common in E-1 and (2) that no facies similar to E-2 has been described from well-studied Mesozoic and Paleozoic eolianites that lack vertebrate skeletal remains.

The orientation of the clay that coats the sand grains (parallel to grain surfaces), the presence of clay at grain contacts, the tendency of clay coats to thicken over embayments in the sand grains, and the absence of meniscus bridges between grains indicate that most of the clays within and adjacent to the concretions are inherited clay rims as described by Wilson (1992). Thus the clays were deposited on the grains prior to their arrival at the site of deposition. Such clays record the reworking of grains that were coated by infiltration of clay- charged water and are common in Quaternary dune sands (Wilson, 1992; Loope and Dingus, 1999). Although the postalluvial burrowing could have destroyed meniscus bridges produced by in situ clay accumulation, the absence of these bridges in the burrow fills of the concretions suggests that this process was not volumetrically important at the depth of concretion development.

Eberth (1993) demonstrated that pedogenic calcite is widespread in structureless sandstones of the Djadokhta Formation at Bayan Mandahu in Inner Mongolia but interpreted the calcite cement of cross-stratal toesets as groundwater calcrete. In contrast, the burrows that cut the sheetlike calcareous concretions of E-2 clearly postdate the onset of carbonate accumulation. The cross-cutting burrows, the location of concretions within the sediments deposited high on the slopes of large bedforms (far above the water table), and the fine grain size of the calcite indicate that concretion development started within the vadose zone. 


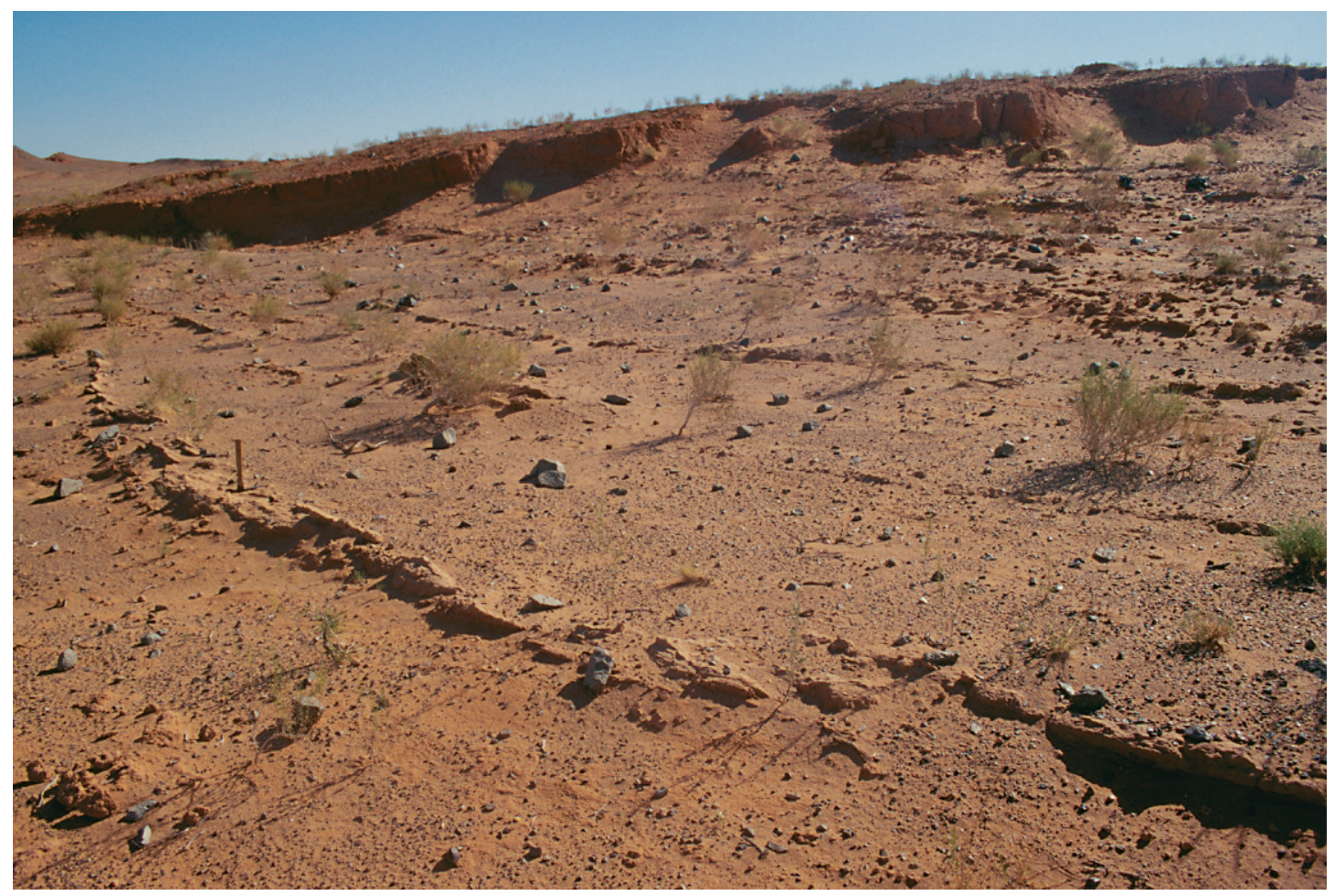

Fig. 4. Cross-stratified, tabular concretions of Facies E-2, exposed southwest of Xanadu, interpreted as early-cemented sheets that developed parallel to stratification within eolian dune deposits.

Pedogenic calcite plays a pivotal role in our hypothesis explaining the preservation of abundant, articulated, and unscavenged vertebrate skeletons at Ukhaa Tolgod (see Sandslide Facies, below).

A recent study (Yang et al., 2003) of the Badain Jaran Desert of western Inner Mongolia, China, provides a Quaternary analog for the caliche zones that we have recognized in the Cretaceous strata at Ukhaa Tolgod. Yang et al. (2003) interpret the many calcite cemented zones that lie parallel to cross-strata within these dunes as evidence that dune migration ceased during episodes of climate amelioration. The cemented zones are generally $8-10 \mathrm{~cm}$ thick. Soil-forming processes were terminated when arid conditions returned and dunes became mobile. In some dunes as many as two dozen cemented zones are present.

The abundance of biogenic structures and grain-rimming clays, plus the presence of pedogenic calcite indicate that the large eolian bedforms upon which these sands accumulated were immobile for at least hundreds, and probably thousands of years. In comparison, the Late Quaternary Nebraska Sand Hills where dunes have been stabilized by vegetation for at least several hundred years, sands are coated by infiltrated clays, but no calcium carbonate has accumulated (Lewis, 1990).

Given the presence of early diagenetic, vadose calcite in this facies, the scarcity of rhizoliths is surprising. Could Late Cretaceous plants survive on dunes? Calcitic rhizoliths are abundant in numerous ancient eolianites (Esteban and Klappa, 1983; Loope, 1988), including the Djadokhta Formation at Bayn Dzak (Loope and Dingus, 1999). Magdefrau (1956) describes a possible example of Early Cretaceous plants that grew on dunes, but the abundant rhizoliths preserved in Paleozoic and Mesozoic eolianites of the Colorado Plateau (all of which are pre-Cretaceous) are developed along horizontal unconformities and do not represent the roots of dune- 

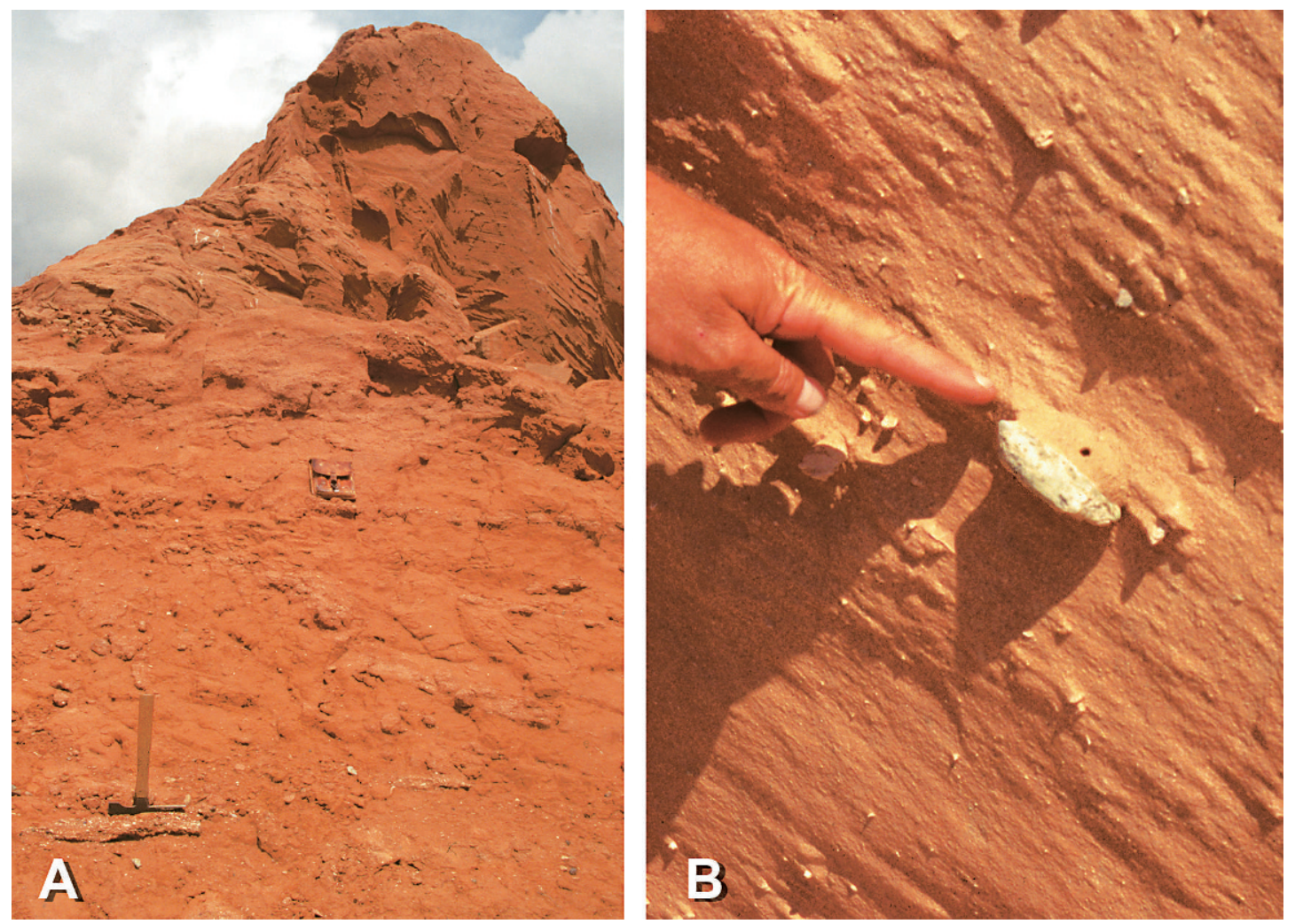

Fig. 5. A. Structureless sandstone with small lens of conglomerate of Facies $\mathrm{S}$ (below hammer), exposed at the base of the Sphinx, interpreted as sand slides down the lee slopes of eolian dunes (sandstone), mixed with fluvial gravel. B. Structureless sandstone with pebbles imbedded in matrix of Facies F interpreted as mass flow composed of a mixture of dune- and stream-derived material.

dwelling plants (Loope, 1988). The large rhizoliths in eolian strata at Bayn Dzak (Loope and Dingus, 1999) appear to record the presence of dune plants - their roots lie parallel to cross-strata (an advantage only within the vadose zone) and laterally adjacent fluvial deposits suggest that streams flowed between contemporaneous dunes.

\section{SANDSLIDE FACIES}

\section{Structureless Sandstones Lacking Oriented} Concretions or Cross-strata (Facies S)

DESCRIPTION: The third sandstone facies, unlike the two described above, lacks physical sedimentary structures and any indicators of a preserved slope-parallel fabric (fig. 5A, B). Isolated or lenticular deposits of granules, pebbles, and cobbles are occasionally present.
This facies is the most fossiliferous at Ukhaa Tolgod. Oviraptorid skeletons preserved on nests of well-arranged eggs, along with perfectly articulated skeletons of tiny mammals and lizards are present. At one locality (Delta Force), a $20 \mathrm{~m}$ thick body of well-sorted sandstones of facies $\mathrm{S}$ abuts the depositional pinchout of eolian cross-strata of facies E-2 that dip at 25 degrees and are at least $24 \mathrm{~m}$ thick. At other localities, such as Downlap Hill, the sloping upper surfaces of well-sorted sandstone bodies of facies $\mathrm{S}$ are downlapped by eolian cross-strata of facies E-1.

On maps 2-6, the structureless sandstone $(\mathrm{Ks})$ is occasionally subdivided into exclusively dune-derived sandstone (Ksd) and crudely flat-bedded sandstone (Ksf), which often contains lenses of larger clasts representing sediments that have washed in from outside the dune field. 
INTERPRETATION: Based primarily on taphonomic evidence that supports rapid accumulation and the presence of large scale crossstrata within the formation, numerous authors have interpreted structureless Djadokhta sandstones as products of violent sandstorms (e.g., Eberth, 1993). Several lines of evidence lead us to interpret these deposits as dunesourced sandslides (Loope et al., 1998, 1999).

Perfect preservation of articulated small lizard and mammal skeletons in this facies strongly suggests that its structureless nature is depositional and not the result of bioturbation. Our sandslide hypothesis is based primarily on the lack of depositional structures and the stratal relationships with facies E-1 and E-2. Somewhat similar deposits have been described from stabilized Quaternary dunefields in the Sahel of Africa and the Great Plains of North America (Talbot and Williams, 1978, 1979; Ahlbrandt and Fryberger, 1981; Sweeney and Loope, 2001). Climate change, dune stabilization, and the attendant accumulation of calcite in the dune deposits led to mass movements that built fans (Loope et al., 1999). Sandslide deposits were downlapped and buried when dunes reactivated.

We cannot cite a Holocene example of animals overwhelmed by mass flows from dunes, and until the publication by Yang et al. (2003; see above) we were also unaware of a dunefield in which dune lee slopes are underlain at shallow depth by calcite-cemented sand. Positive pore water pressure within steeply sloping unconsolidated material is a well-known trigger for mass wasting events (Graham, 1984). Dunefields that lack slopeparallel barriers to the flow of infiltrating water are not likely to generate large mass flows. Thus, many unusual conditions were required to generate the fossiliferous sediments of the Djadokhta Formation: (1) large dunes formed in a subsiding sedimentary basin; (2) dunes became stabilized; (3) dust flux, average rainfall, and duration of dune stability allowed development of calcite zones beneath dune lee slopes; (4) sufficient food and water were available to attract large animals to the site; (5) rare, heavy rainfall events caused perched water tables to form under dune slopes. Yang (personal commun., August, 2003) notes that rain-triggered sand- slides are common on the lee slopes of large dunes in western China.

The crudely flat-bedded sandstone (Ksf) was likely deposited by ephemeral streams entering the dunefield from adjacent highlands. Possible modern analogs are the mass flows and hyperconcentrated flows generated by the breaching of dune dams by floods entering the Namib sand sea in southwestern Africa (Svendsen et al., 2003).

\section{Conglomerates (Facies C)}

Description: Conglomerates composed primarily of igneous clasts ranging in size from granules to boulders up to $85 \mathrm{~cm}$ in diameter are occasionally interbedded with the sandstone facies described above (fig. 6). The igneous clasts are grayish green (10 GY 5/2) to dark yellowish green (10 GY 4/4) and consist of an andesitic matrix with phenocrysts of potassium feldspar. Clasts range in shape from angular to moderately well rounded. Usually these conglomeratic beds are distinct from other units; however, lenses of similar conglomeratic material are occasionally contained in the sandslide deposits of facies S. Vertebrate fossils are absent. On the facies maps 2-6, this facies is represented by Kc.

INTERPRETATION: The conglomerates clearly indicate the presence of a topographic high near the Ukhaa Tolgod area. The angular nature of numerous clasts indicates that transport distance from the topographic high to the Ukhaa Tolgod dunefield was not great. The orientation of channels containing the conglomerates suggests that current direction was from northeast to southwest. The conglomerates were probably deposited on alluvial fans that built out from the topographic high and impinged on the dunefield, which probably occupied the central area of the paleobasin. Similar topographic regimes have been reported from other areas in the Gobi, including Bayan Mandahu in northern China (Eberth, 1993).

\section{Interdune Facies}

Mudstones and Siltstones (Facies M).

DESCRIPTION: Moderate reddish-brown (10 $\mathrm{R}$ 4/6) to dark reddish-brown (10 $\mathrm{R}$ 3/4) 


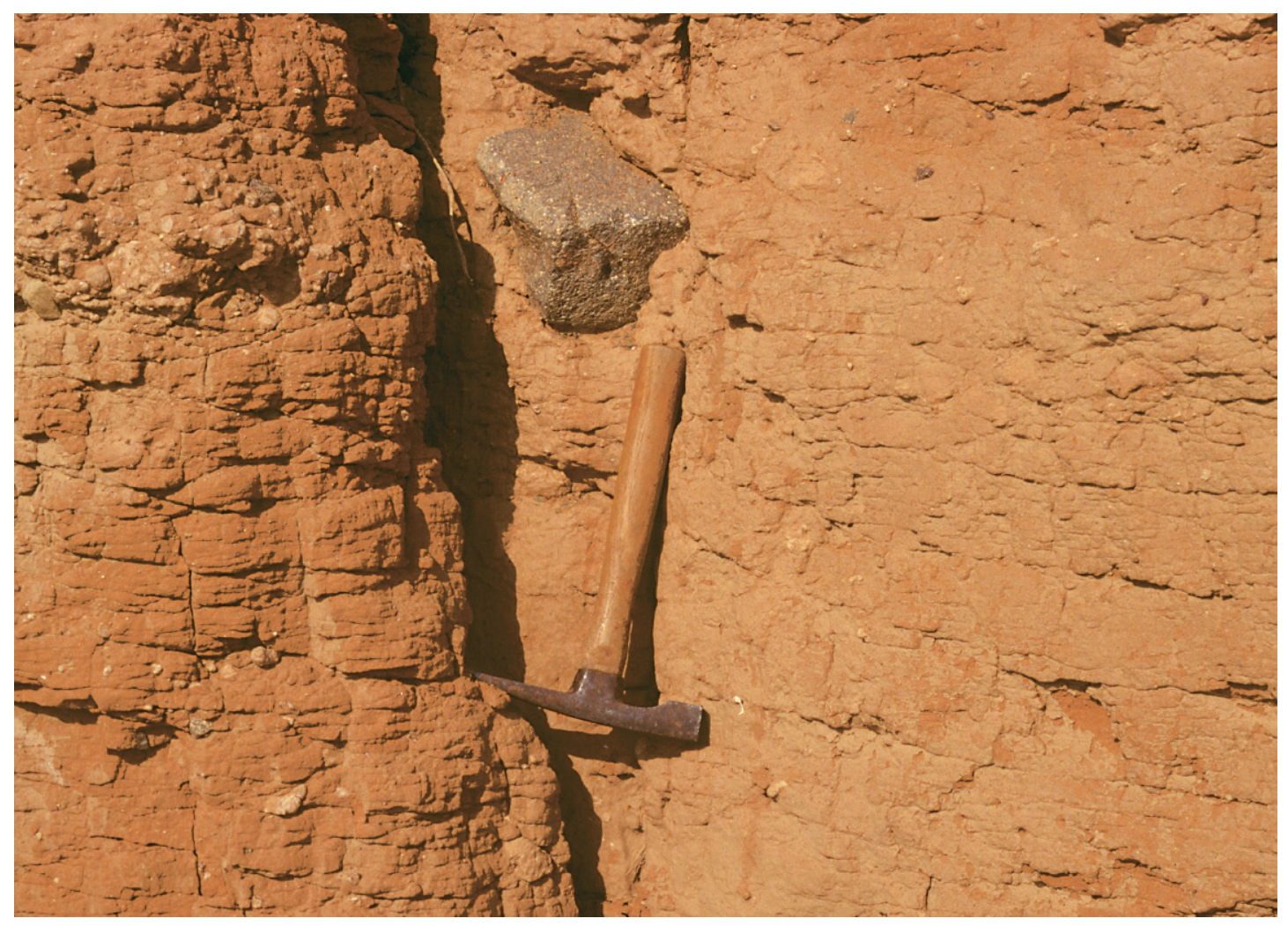

Fig. 6. Andesitic cobble with phenocrysts of potassium feldspar adjacent to lens of white, caliche pebble conglomerate of Facies C, exposed above Death Row, interpreted as fluvial deposit.

siltstone contains small amounts of clay and often contains a substantial fraction of fine sand (fig. 7). The siltstone weathers into small blocks that break apart easily. Rip-up clasts are occasionally present. The siltstone beds can be as much as $20 \mathrm{~cm}$ thick; however, the beds are not laterally continuous over large geographic areas. Based on mapping and correlations, the most extensive set of interdune layers extends across a one square $\mathrm{km}$ area in the eastern portion of the Ukhaa Tolgod Basin. Contacts with over- and underlying units are sharp. Remains of vertebrates are rare. On maps 2-6, this facies is represented by $\mathrm{Km}$.

INTERPRETATION: The siltstones appear to represent sediments deposited at the bottom of small ephemeral ponds or lakes that formed when corridors between the dunes at Ukhaa Tolgod were flooded. Although skeletal remains of vertebrates are rare, two fossil turtle shells with partial postcrania have been collect- ed from these deposits, suggesting that the ponds did occasionally serve as sources of water for some of the vertebrates at Ukhaa Tolgod.

\section{Map of Sedimentary Facies}

The geologic units exposed in the Ukhaa Tolgod drainage basin were mapped in 1997 on air photos taken at the end of the 1996 field season (maps 2-6). The units mapped are labeled in the legend on the index map (map 2). Major fossil localities are plotted by name on the maps. The locations of individual fossil specimens are plotted according to taxon, as specified by symbols listed in the legend. The distributions of the five sedimentary facies found at most localities between Downlap Hill in the southwest and Zofia's North in the northeast are discussed below in Stratigraphic Sections and Schematic Cross Sections.

Across the Ukhaa Tolgod drainage basin on the southern ridge, a series of poorly exposed 


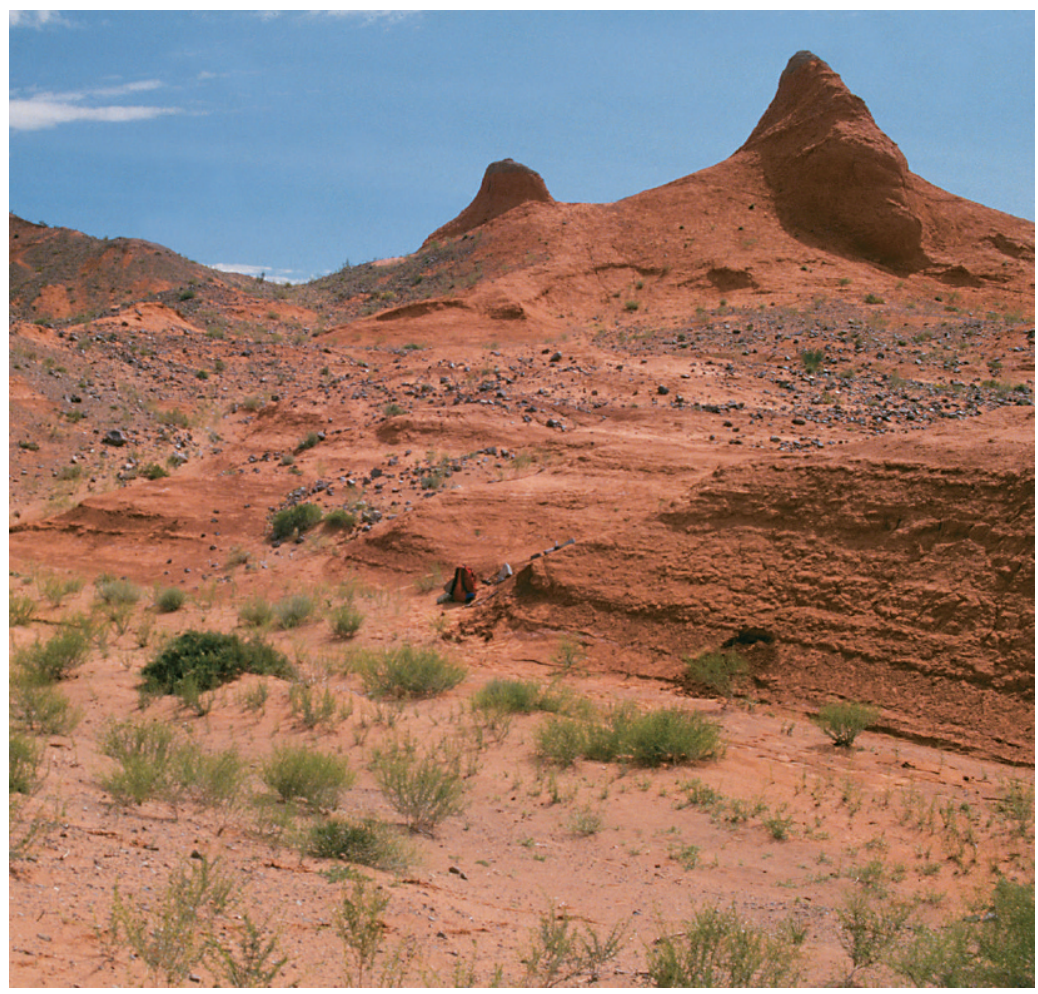

Fig. 7. Reddish brown siltstone of Facies M (especially to right of pack) exposed near the eastern base of Camel Humps, interpreted as interdune deposits formed in ephemeral lakes and ponds.

patches of Facies $\mathrm{S}$ and $\mathrm{E}-1$ is capped by Quaternary pediment. One dinosaur nest has been collected from the southernmost patch of Facies S. This locality is named Uranus.

At Xanadu SW, a fault trending essentially east-west cuts the exposures uplifting the southern block and down-dropping the northern one. The southern ridge between Xandu SW and First Strike is capped by Quaternary pediment.

Midway between Camel Humps and First Strike, three small outcrops of cross-stratified dune sand cap the southwest end of the northern edge of the basin. The middle one is cut by a small, north-south trending fault, with the eastern block uplifted and the western block down-dropped.

\section{Stratigraphic Sections and Schematic Cross Sections}

The vertical and lateral stratigraphic distributions of the five facies were documented in
11 stratigraphic sections and four schematic cross sections within the Ukhaa Tolgod drainage basin. The stratigraphic sections were measured with a Jacob staff and Brunton compass (fig. 8). The location of each can be seen on maps 3-6.

DownlaP Hill: Figure 9 (top and bottom) depicts the lateral relationships at the site, where Facies E-1 forms the base of the western edge of the hill (map 3). The overlying Facies $\mathrm{S}$ contains faint, low-angle bedding planes that dip 5-10 degrees northeast and may represent contacts between individual debris flows that formed the alluvial fan. Above, cross-strata of Facies E-1 fills in a shallow depression that formed the surface of the fan. They dip about 25 degrees to the northeast at a bearing of 55 degrees in relation to magnetic north, and clearly represent the downlap of the dune over the fan surface as it migrated to the northeast.

Figure 8 documents eight sections along the main axis of the drainage basin, from Delta 
Force/Granger's Hill in the southwest (at left in the illustration) to First Strike in the northeast (at center right). Three lithologic units are especially useful for establishing lithostratigraphic correlations between these sections. First, a distinctive bed containing abundant, small, white, caliche pebbles can be lithostratigraphically correlated from Granger Hill to First Strike. Second, a distinctive interval containing bed(s) of Facies $\mathrm{M}$ is consistently found below the white, caliche pebble layer at Ankylosaur Flats, Camel Humps, SW of Xanadu, and First Strike. Finally, a lithologically distinct bed of Facies $\mathrm{C}$ containing andesitic clasts caps the sections at Ankylosaur Flats and Camel Humps.

Delta Force/Granger Hill: Vertebrate fossils including an articulated oviraptorid skeleton are common in the basal $7 \mathrm{~m}$ at Granger Hill (map 3). Sandslides of Facies S, which cap the section at Delta Force (fig. 10), have produced a well-preserved articulated skeleton of Deltatheridium. A pair of intertwined oviraptorid skeletons was excavated at Romeo and Juliet to the northeast (map 3).

AnKylosaur Flats: This stratigraphic section runs from near the local bottom of the Ukhaa Tolgod drainage basin to the top of the bluffs overlooking Ankylosaur Flats (fig. 11, top; map 4). The lateral relationships of strata exposed along the ridge between Ankylosaur Flats and the Sphinx are illustrated in figure 11 (bottom). The strata pictured form the basis for the Ankylosaur Flats and Sphinx sections.

Basal concretionary sheets of E-2 in the southwest correlate laterally with Facies $\mathrm{S}$ to the northeast, which crops out below a lens of Facies M. Above, in situ remains of articulated partial ankylosaur skeletons are especially abundant on the flats formed by Facies S, while several in situ articulated, oviraptorid specimens, some preserved in brooding position atop nests of eggs, have been excavated from Facies $\mathrm{S}$ just below the unit of Kwp. Numerous small concretions containing wellpreserved skulls of mammals and lizards occur as float and cannot be assigned with certainty to this stratigraphic interval. In general, this fossil locality is called Ankylosaur Flats.

On the slope below the middle portion of the ridge, another thin vaguely cross-stratified unit crops out, representing the northeast migration of a small dune across the sandslide sequence. The zone of Kwp marks a period of incipient soil formation at the top of this lower sandslide sequence. Above Kwp, another unit of Facies $\mathrm{S}$ contains numerous partially articulated oviraptorid specimens.

Along the southwestern half of the ridge above Kwp, units of Facies $\mathrm{S}$ run all the way up to the base of the capping Facies C. However, to the northeast a prominent unit of Facies E-1 is exposed, which forms the bulk of Sphinx Butte and clearly represents the northeast migration of a large dune over the laterally equivalent units of Facies $\mathrm{S}$ exposed along the ridge to the southwest.

Sphinx: A butte, called the Sphinx (fig. 12, map 4), juts out from the northern edge of the Ukhaa Tolgod drainage basin. Individual beds of Facies $\mathrm{S}$ at the base attain thicknesses of 50 to $75 \mathrm{~cm}$, possibly providing some sense of the thickness of distinct debris flow units that moved down the dunes. Nests of dinosaur eggs and abundant eggshell fragments, along with articulated partial oviraptorid skeletons are common.

Above, cross strata of E-1, equivalent to the interval of Facies $\mathrm{S}$ between the 26 and $38 \mathrm{~m}$ marks in the Ankylosaur Flats section, are occasionally deformed by concave-up folds of various sizes interpreted to represent tracks of large vertebrates (Loope et al., 1998). Rhizoliths are the only other fossils present.

Facies $\mathrm{S}$ caps the Sphinx section and contains calcareous nodules that occasionally yield skulls of mammals and lizards. Although they usually occur as float, they can be assigned to this interval because it represents the top of the section.

Sugar Mountain: Between the Sphinx and Camel Humps lie intermittent exposures of Facies S (fig. 13, map 4). These represent the renewed mass wasting deposits at the base of the dunes represented by Facies E-1 at the Sphinx. Associated remains of Protoceratops are especially abundant, and near the top of the interval, several, closely associated and articulated skeletons of small placental mammals including Ukhaatherium nessovi Novacek et al., 1997 (= gen. nov., Dashzeveg et al., 1995: 448) have been collected.

CAmel Humps Basin: The basal exposures contain beds of Facies $\mathrm{S}$ interbedded with 


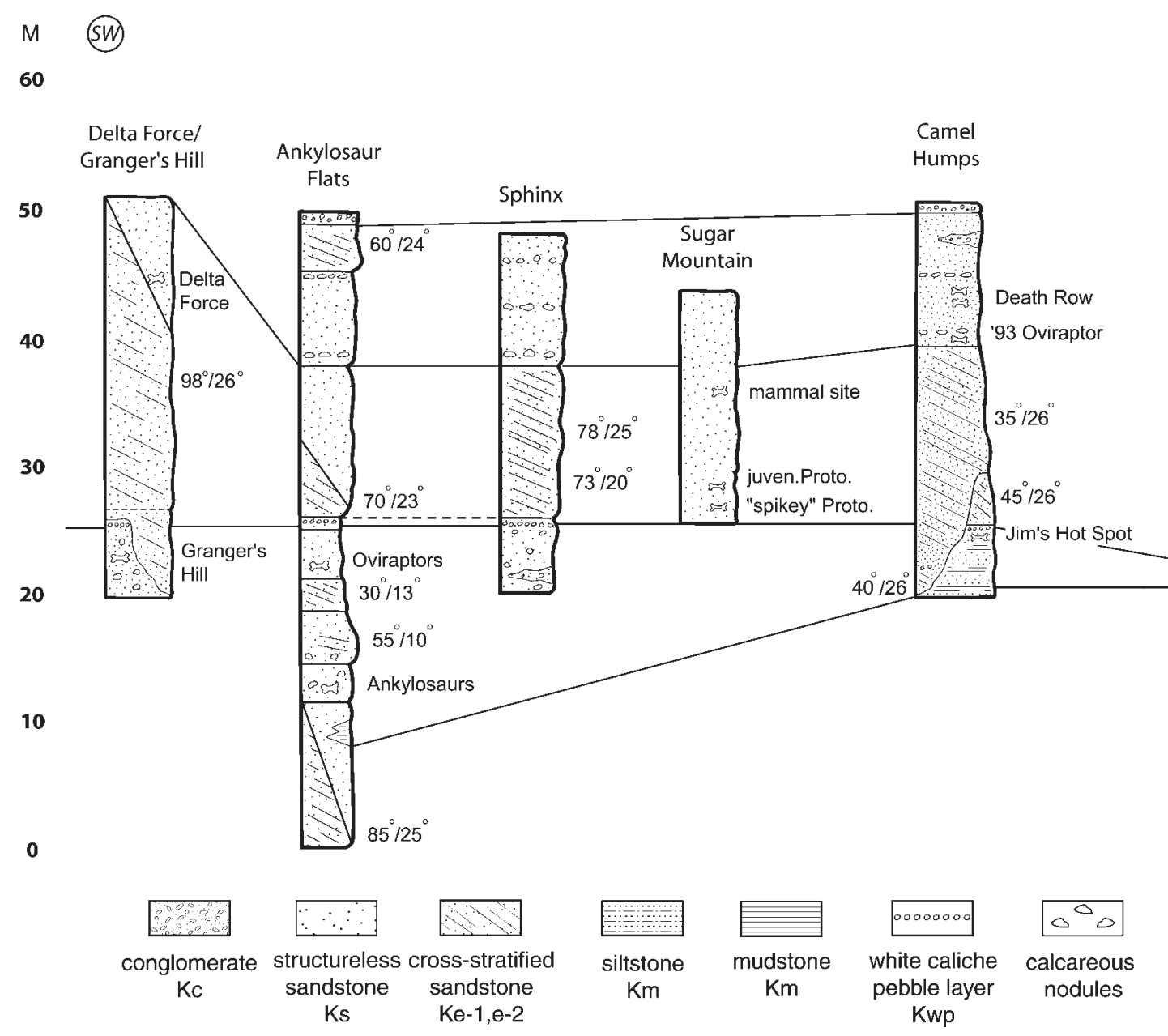

Fig. 8. Correlation chart of stratigraphic sections at Ukhaa Tolgod, including Zophia's Hill area (at far right). Sections are labeled and positions are plotted on maps 3-6. Lithologic key is included. Symbols such as $26^{\circ} / 98^{\circ}$ represent the amount and azimuth of dip for cross-strata, which are inferred to represent the paleowind direction.

interdune deposits of Facies $M$ (fig. 14, map 4), which lithostratigraphically correlates with those near the base of the eastern portion of the Ankylosaur Flats section. These mudstones have yielded two fossil turtles, with preserved shells and other postcrainal remains, as well as a few partial skeletons of Protoceratops. The basal units of $\mathrm{M}$ and $\mathrm{S}$ (fig. 15) can be traced northeast along the base of the ridge where they abut a unit of E-1. Just above the basal mudstones to the south of Camel Humps on a small ridge jutting out from the base of the buttes, Kwp contains abundant fossil skulls of lizards at Jim's Hot Spot.
The northern ridge of the basin contains many of the same units seen in the southern ridge. The unit of E-1 seen below Camel Humps Buttes can be traced through the small drainage of the basin to where it dips eastward across the northern ridge, lapping down across the basal, fossiliferous unit of Facies S (fig. 16, top). This unit of E-1 laterally correlates with the E-1 unit that forms Sphinx Butte and appears to represent a remobilization of that dune. However, the deposition of the E-1 unit at Camel Humps postdated that at the Sphinx, because the bearings and dips of the crossstrata indicate a northeast migration of the 
(NE) $M$

60

50

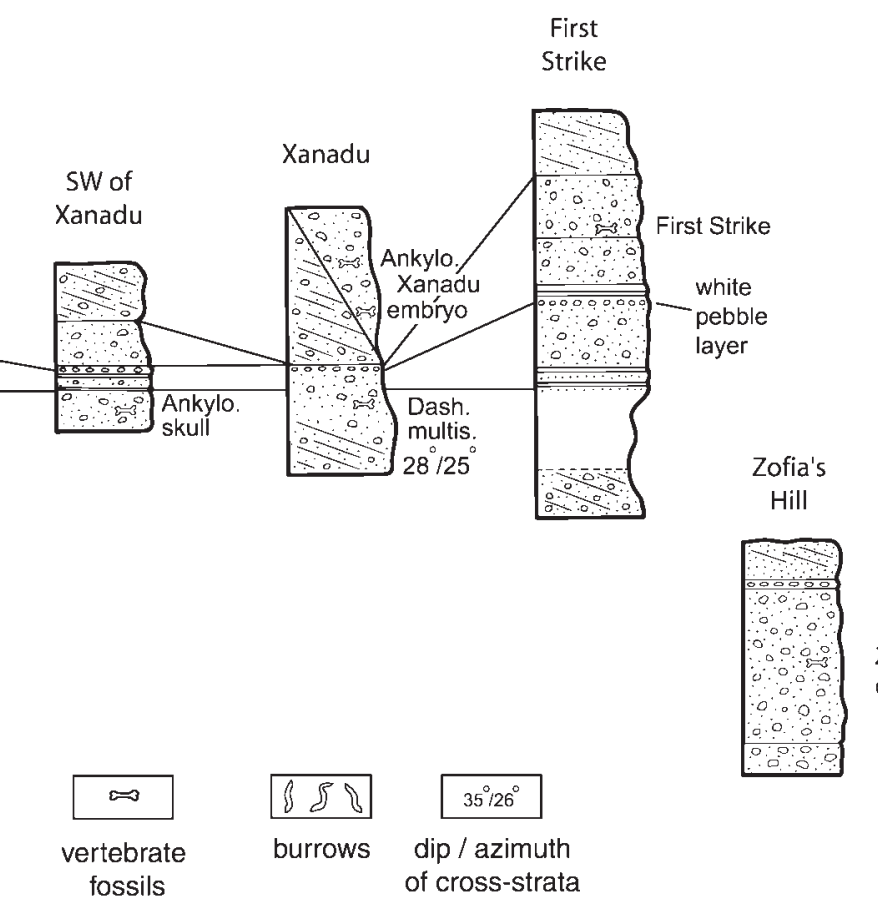

dunes with an intervening period of sandslide development between Sugar Mountain and Camel Humps. This dune appears to have downlapped over the intervening sandslide deposits between the Sphinx and Camel Humps. The period of dune remobilization was not extensive, however, as Facies S comprises most of the laterally equivalent deposits along the northern ridge.

Above, a unit of Facies $\mathrm{S}$ is laterally equivalent to that at the top of the Sphinx. Near the middle of this unit at Death Row, numerous associated and articulated oviraptorid specimens, as well as specimens of Protoceratops, an ankylosaur, and a dinosaur nest were collected (fig. 16, bottom). The fossils occur within a very limited interval, suggesting that this level may have represented a distinct topographic surface on the sandslide deposits. Above that interval, occasional lenses of igneous pebbles and isolated cobbles, identical to those in the capping unit of Facies C, appear to document the approach of a coarse-grained alluvial fan from outside the dunefield that eventually overran this portion of the dunefield and deposited the capping conglomerates. The compositional similarities strongly suggest that the capping conglomerate is Cretaceous.

Xanadu Southwest: The basal Facies S has yielded a well-preserved ankylosaur skull. Above, Facies $\mathrm{M}$ correlates with basal beds of $M$ on the southern side of Camel Humps Basin. The section is capped by Facies E-2 (fig. 17, map 5).

XANADU: The section's base, formed by E2 , lies at the bottom of the main drainage for 

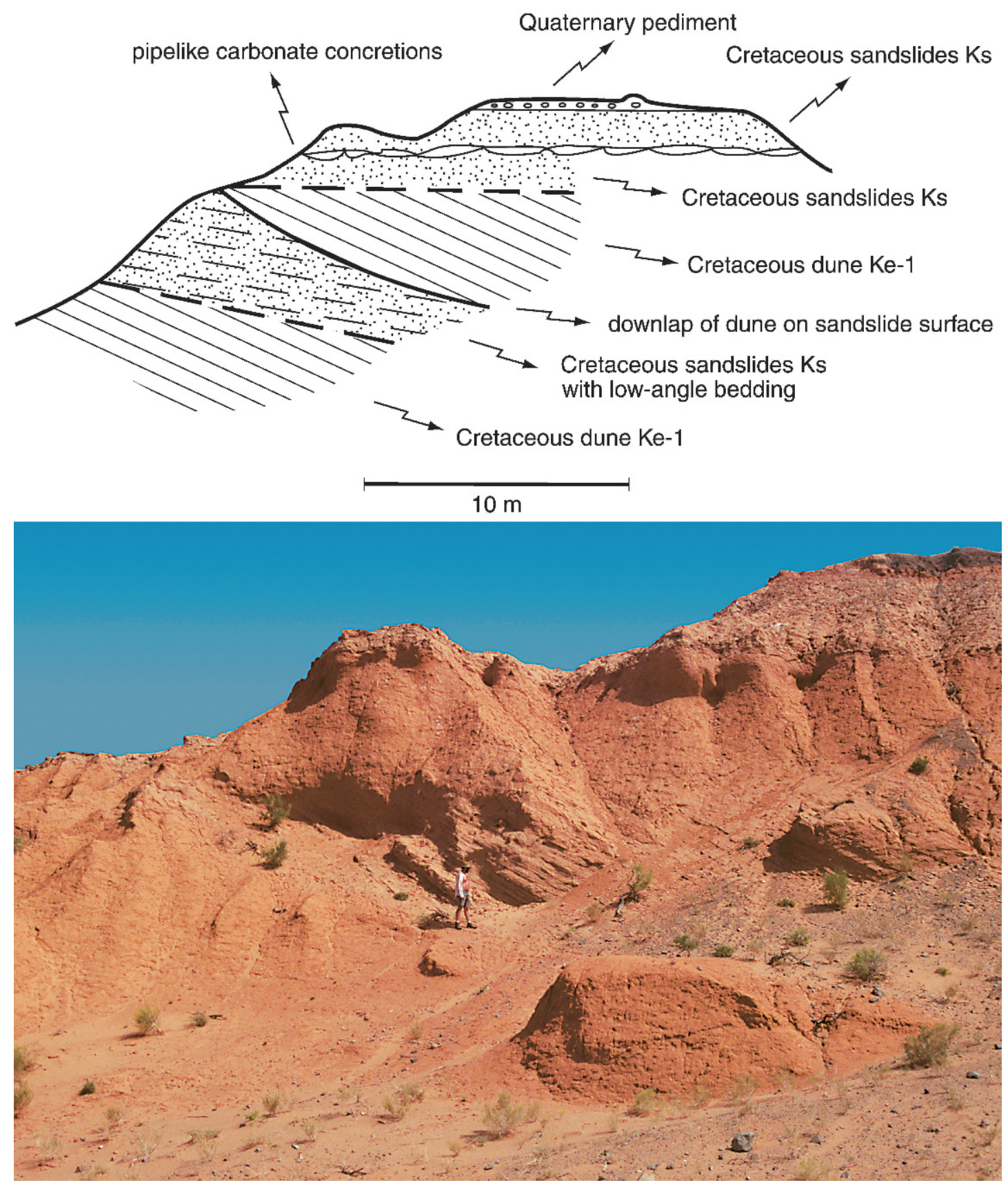

Fig. 9. Top: Schematic cross section of exposures at Downlap Hill. Location of site is labeled on map 2. For lithologies in all cross sections, see fig. 8. Bottom: View looking north at Downlap Hill, with low-angle bedding in sandstone of Facies $\mathrm{F}$ (below person) underlying distinctly cross-stratified sandstone of Facies E1 (slightly above and to right of person). See top for interpretation. 


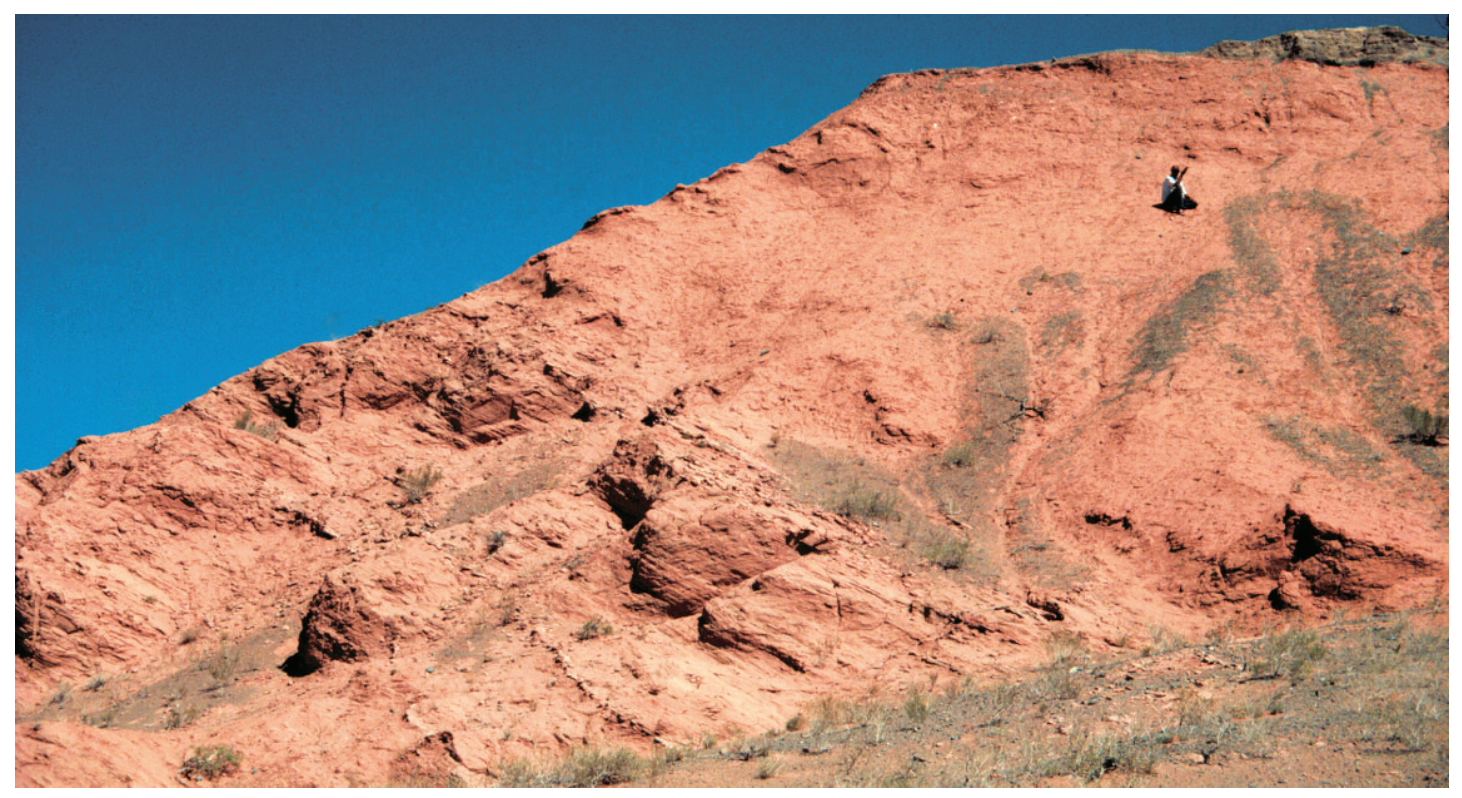

Fig. 10. Exposures at Delta Force showing contact between vaguely cross-stratified sandstone of Facies E-2 (lower left), interpreted as eolian dune deposits, and structureless sandstone of Facies S (upper right), interpreted as dune-derived sandslide/debris flow deposits.

the Ukhaa Tolgod Basin (map 5). But to the north, Facies $\mathrm{S}$ forms the base of the section and appears to represent sandslides building out from the laterally equivalent dune sands to the west. Calcareous nodules in Facies $\mathrm{S}$ have produced a well-preserved multituberculate skull and abundant eggshell fragments.

Above the white pebble layer (fig. 18), fossils from Facies $\mathrm{S}$ at Xanadu include abundant dinosaur nests, an oviraptorid embryo, partially articulated ankylosaur skeletons, Protoceratops skeletons, juvenile dromaeosaur skulls, and skulls of mammals and lizards in nodular calcareous concretions.

First Strike: The basal unit of E-2 (fig. 19A, map 5) probably corresponds laterally to the E-2 at the base of Xanadu. The Facies $M$ forming the base of the butte at First Strike correlates with the basal $\mathrm{M}$ at Camel Humps and Xanadu SW. Lizard and mammal skulls from the overlying Facies $\mathrm{S}$ are preserved in calcareous, nodular concretions as float, and Kwp occurs near the top of this unit (fig. 19B). A stratigraphically higher unit of Facies $\mathrm{S}$ produced numerous fossil skulls of lizards and mammals preserved in nodular calcareous concretions. These included the first fossils discovered in the Ukhaa Tolgod Basin in 1993.

Zofia's Hill, Zofia's Middle, AND ZOFIA's North: Figure 8 (far right in illustration) and map 6 document three stratigraphic sections along the northernmost extent of the Ukhaa Tolgod drainage basin between Zofia's Hill in the southwest (fig. 20A), Zofia's Middle in between (fig. 20B), and Zofia's North in the northeast.

The basal Facies $\mathrm{S}$ at Zofia's Hill yielded numerous skulls of mammals and lizards in nodular calcareous concretions.

Six $\mathrm{m}$ above the prominent unit of Facies $\mathrm{C}$ at Zofia's Middle (fig. 20B) lies a unit of Facies $\mathrm{S}$, containing nodular calcareous concretions occurring as float with fossil skulls of lizards and mammals. This unit correlates with the fossiliferous unit of Facies S at Zofia's Hill.

The thin bed of Facies C at Zofia's North can be laterally traced into the similar unit at the base of the Zophia's Middle section. An overlying unit of Facies $\mathrm{S}$ contains calcareous nodules occurring as float that contain fossil skulls of lizards.

At present, no distinctive lithologic units have been identified that can be used to 


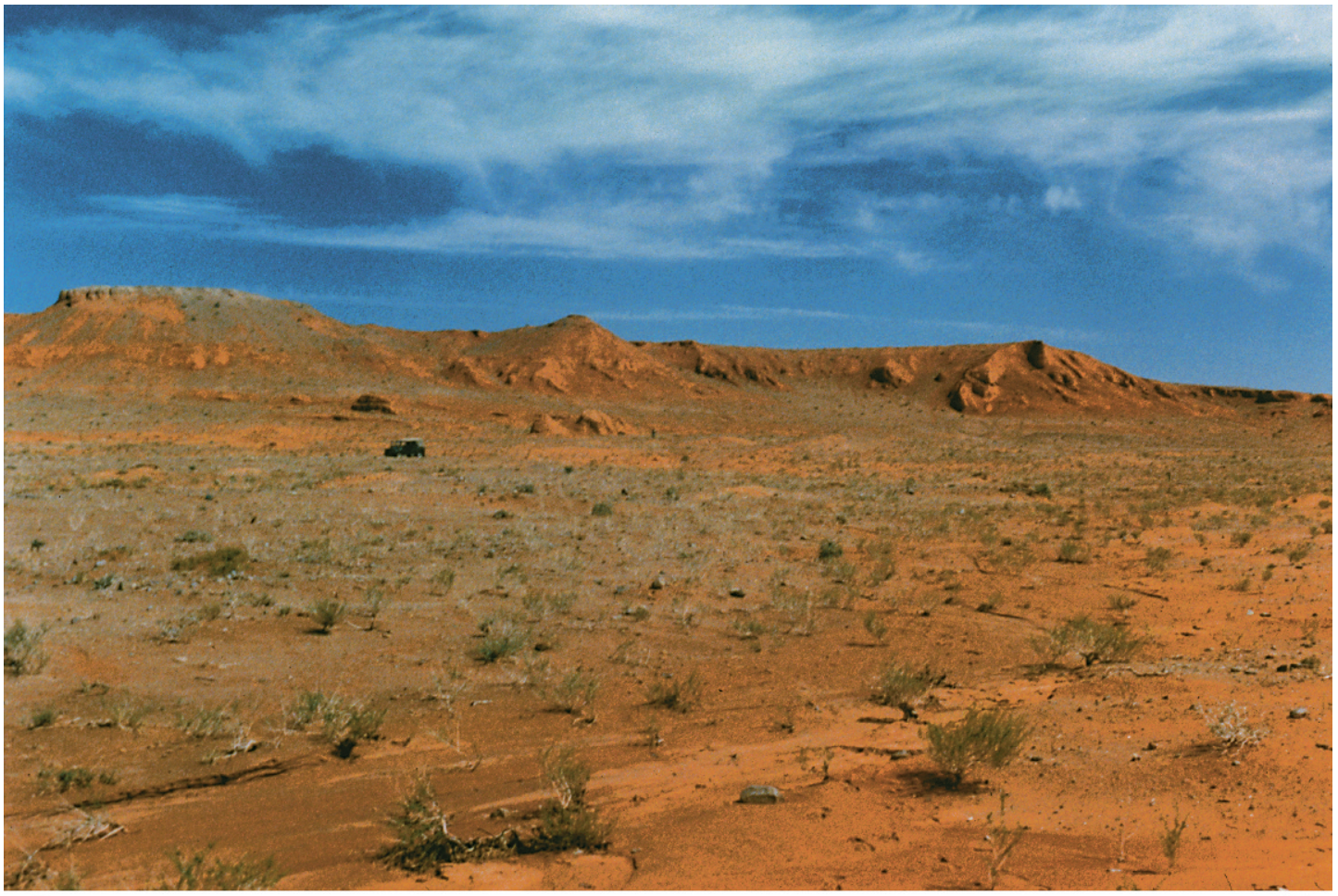

Cretaceous conglomerate $\mathrm{Kc}$

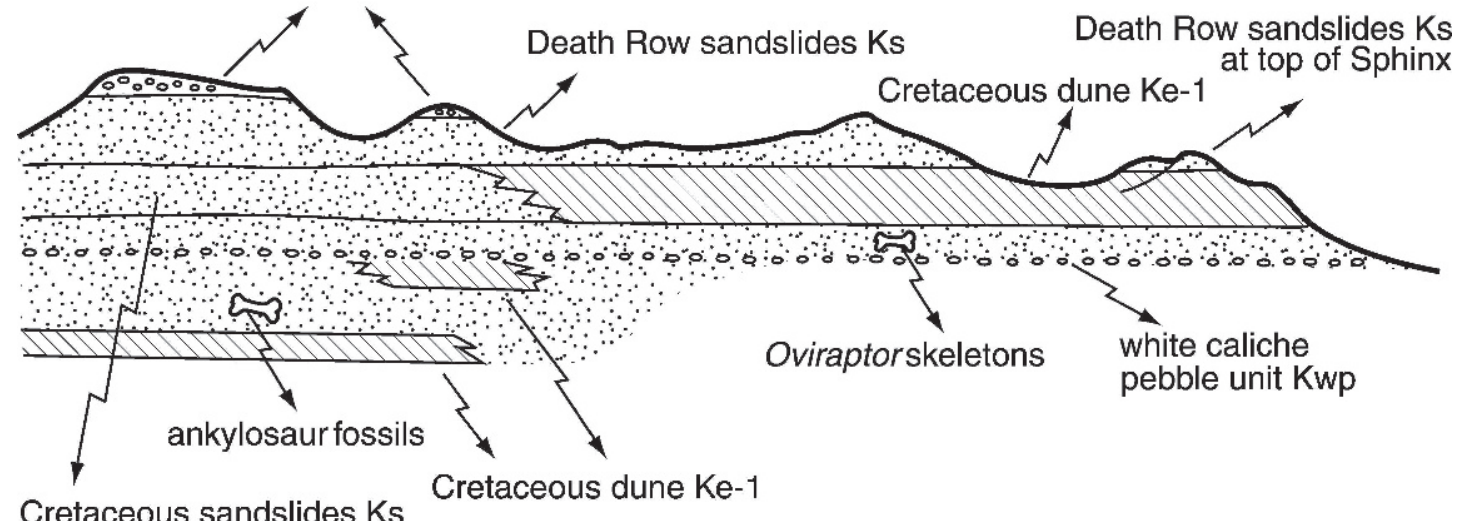

Cretaceous sandslides Ks

\section{$100 \mathrm{~m}$}

Fig. 11. Top: Panoramic view of exposures at Ankylosaur Flats, including bluffs above flats. Sphinx is located just past the right edge of the photo (vehicle near left center for scale). Bottom: Schematic cross section of exposures at Ankylosaur Flats. Location of site is seen on maps 1 and 2, from Sphinx to capping Kc above western edge of Ankylosaur Flats. Includes same complex of sandslides and admixed fluvial deposits seen at Death Row. 


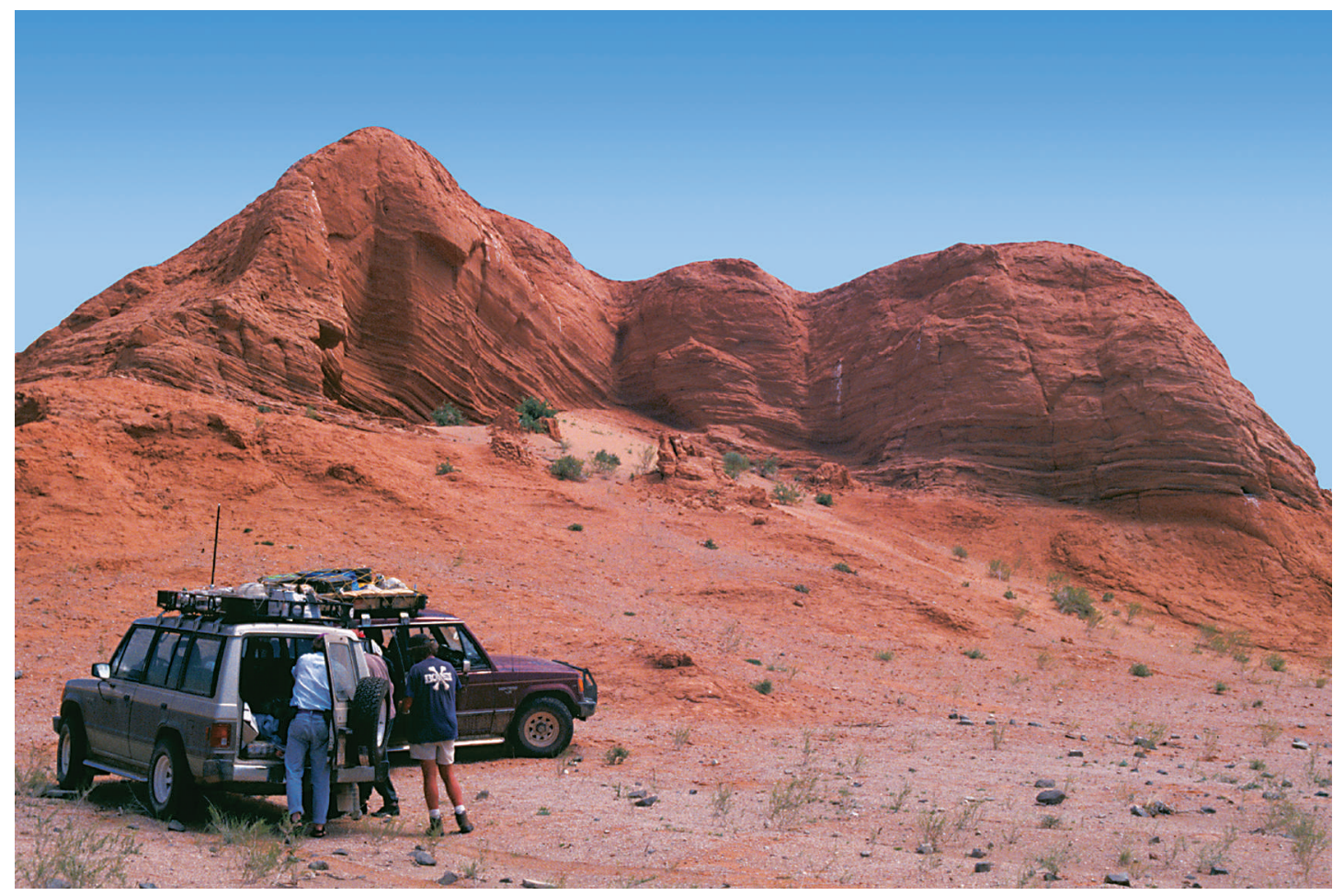

Fig. 12. Sphinx, showing low-relief exposures of structureless sandstone (Facies $\mathrm{S}$ ) at the base and crossstratified sandstone (Facies E-1), which forms the butte.

establish lithostratigraphic correlations between the three sections in the Zofia's Hill region and the eight sections to the south. However, measurement and calculation of the strata's local dip can be used to infer the superpositional relationship.

\section{Calculation of Local Dip and Its} ImPlication for the Stratigraphic Position of the Sections at Zofia's Hill

The local dip of the lithostratigraphic units can be estimated in two ways that yield very similar results. First, the bed of conglomerate in the Zofia's Middle section is exposed over a distance of about $100 \mathrm{~m}$ in the drainage trending north-south that runs along the western margin of the outcrops at Zofia's Hill. Using the inclinometer on a Brunton compass, the apparent dip of the conglomerate, as seen in cross section within the outcrop, was estimated to be about 2.5 degrees to the south.
This estimate corresponds closely with the dip of the siltstones exposed in the areas around Camel Humps and Xanadu SW sections, as calculated on the basis of a geometric construction using the physiographic map (map 1). Using an altimeter, the elevations of the siltstones were estimated at the base of the southern ridge at the south end of Camel Humps Basin, on the northern flank of Camel Humps Basin, and at Xanadu SW. These siltstones are lithostratigraphically correlated with one another because they are the only siltstones exposed in each section, and they immediately underlie the zone of small, white, caliche pebbles in each section. The gradient observed between the exposures at the northern and southern ends of the Camel Humps Basin (line A-B) was used to estimate the position of the siltstone at the same elevation of the siltstone exposed at Xanadu SW. A line connecting points of equal elevation in the Camel Humps and Xanadu SW areas (line B-C) defines the strike of the 


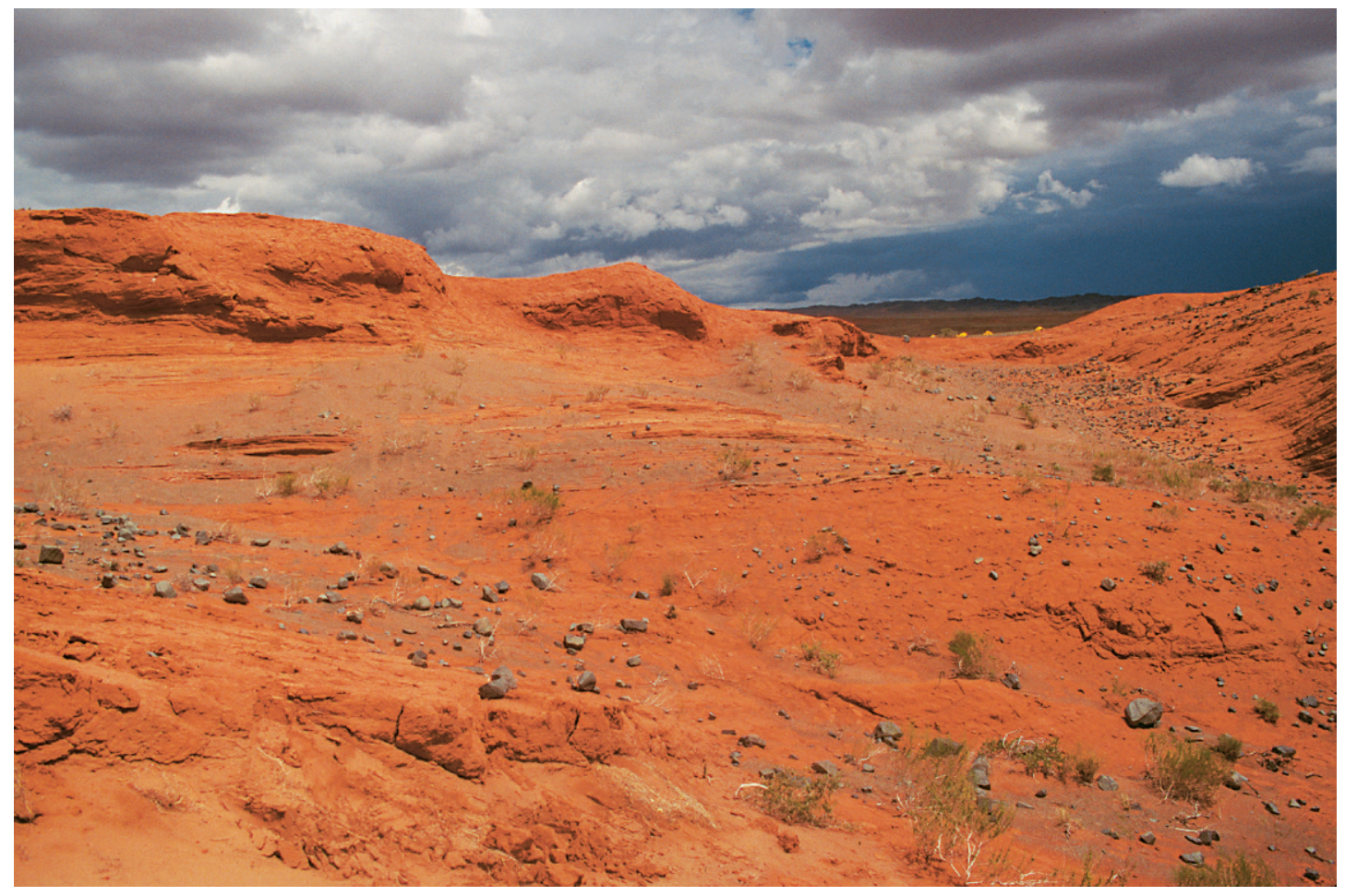

Fig. 13. View looking northeast across low-relief exposures of structureless sandstone (Facies S) at Sugar Mountain, between the Sphinx and Camel Humps.

siltstone-about $70^{\circ} \mathrm{NW}$. The dip of the siltstone, based on calculating the tangent of the angle of dip from the elevation difference between the siltstones on the southern edge of Camel Humps Basin and the elevation along the line of strike divided by the distance between the line of strike and the siltstone on the southern flank of Camel Humps Basin (line $\mathrm{A}-\mathrm{D}$ ), is $2.4^{\circ}$ to the $\mathrm{SW}$.

Knowing the strike and dip of the beds in the Ukhaa Tolgod Basin allows one to calculate the projected stratigraphic position of the units at Zofia's Hill in relation to those at Camel Humps. A line of strike is drawn through the conglomerate exposure near Zofia's Hill (line E-F). Line A-F, which is perpendicular to $\mathrm{E}-\mathrm{F}$ then represents the direction of dip. Knowing the angle of dip $\left(2.4^{\circ}\right)$ and the distance between the line of strike $(\mathrm{E}-\mathrm{F})$ and the exposures of siltstone at Camel Humps (line A-F) allows one to calculate the projected elevation of Zofia's conglomerate at Camel Humps. The calcula- tion suggests that the conglomerate in the Zofia's Middle section and the laterally equivalent siltstone in the Zofies North section would fall about $28 \mathrm{~m}$ below the mudstone at the southern edge of Camel Humps Basin.

\section{DISCUSSION}

Comments on Fossil Preservation: Although none of the fossils at Ukhaa Tolgod were collected from strata that can, using the well-tested criteria of Hunter (1977, 1981), be interpreted as eolian, they commonly do lie adjacent to eolian deposits (see maps 3-6). Can the debris flow hypothesis developed at Ukhaa Tolgod explain the occurrence of fossils at other Gobi localities? Fastovsky et al. (1997) report the presence of abundant vertebrate fossils in cross-stratified sands at Tugrugyin-Shireh. The cross-stratified sands are interpreted to represent the migration of eolian dunes, and we concur. Structureless sandstones are, however, also present at 


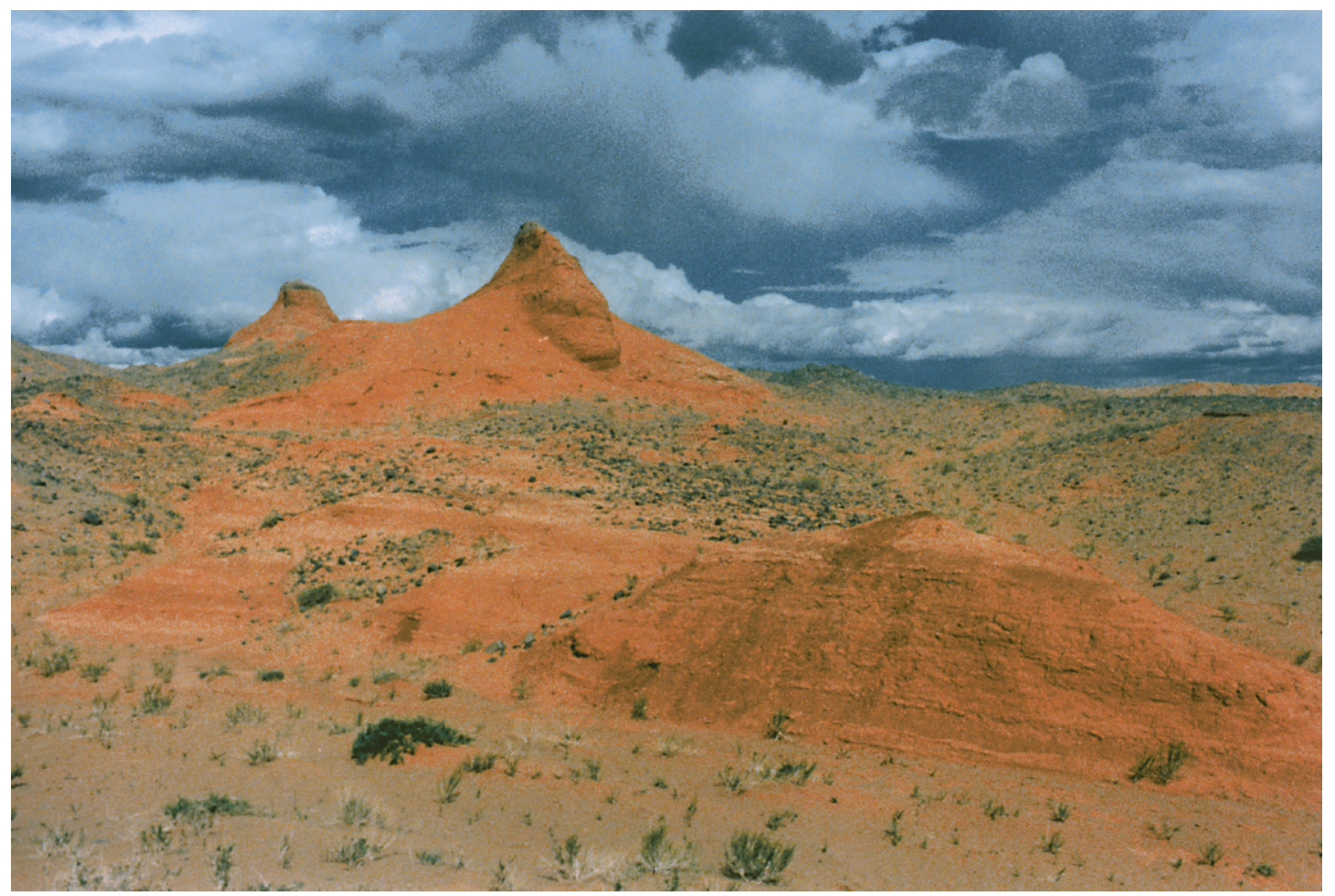

Fig. 14. View looking east showing low ridge composed of siltstone (Facies M) below buttes of Camel Humps.

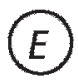

\section{Camel Humps}

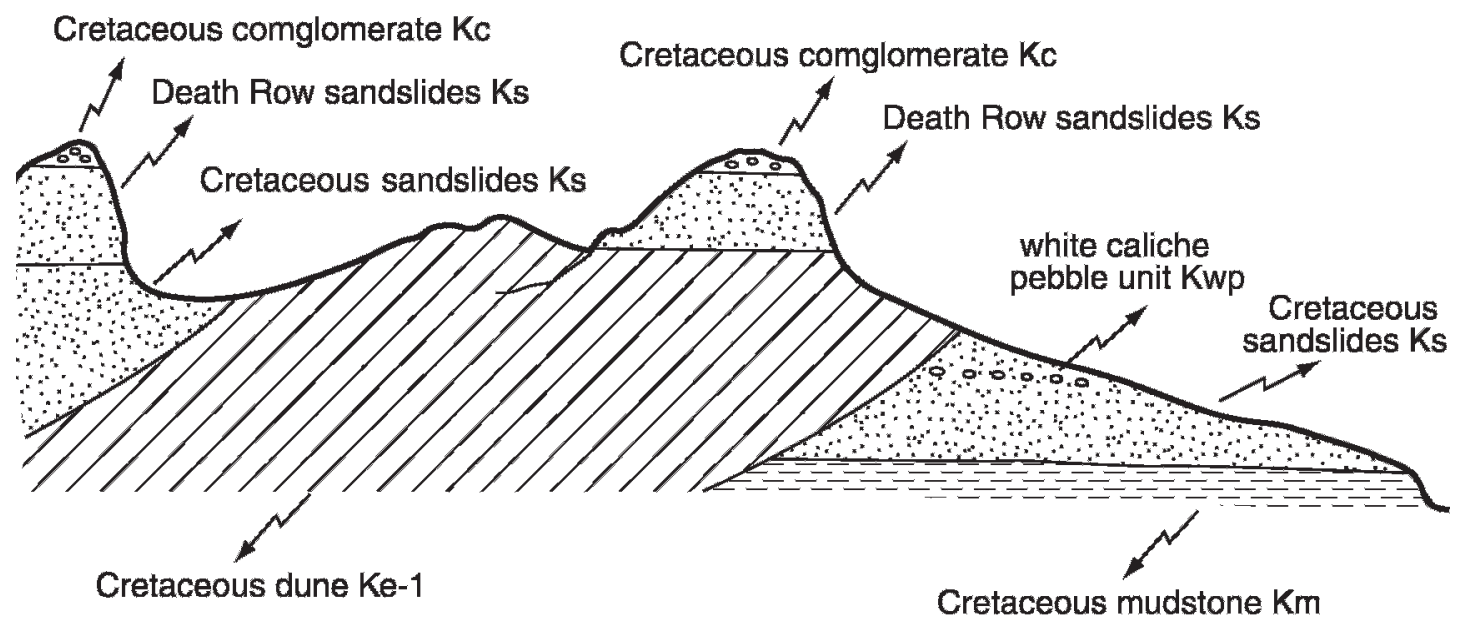

$50 \mathrm{~m}$

Fig. 15. Schematic cross section of exposures on south side of Camel Humps Basin containing Camel Humps locality. Location is seen on maps 1 and 2. 
Tugrugyin-Shireh, and the articulated dinosaur skeletons we observed during our reconnaissance in July 1998 lie within these structureless sands. If vertebrate fossils are preserved within (as opposed to adjacent to) cross-stratified eolian sands at Tugrugyin-Shireh as reported by Fastovsky et al. (1997), this contrasts with the lack of vertebrate fossils in cross-stratified eolian sands at Ukhaa Tolgod (Loope et al., 1998, 1999, and this paper) and Bayan Mandahu (Eberth, 1993).

Eberth (1993) describes both cross-stratified and structureless sandstones at Bayan Mandahu. Whereas the structureless sandstones contain vertebrate fossils, the cross-stratified sandstones contain only trace fossils. Eberth interprets both facies to represent products of eolian dune deposition, with structureless sands possibly representing interdune deposits of zibars - low relief dunes composed of grains too coarse to allow the development of a slip face (Kocurek, 1996). We concur with the assignment of the cross-stratified sand to eolian facies. However, we are posing an alternative explanation for the structureless sands at Ukhaa Tolgod, which we feel are better explained as sandslide deposits built up at the base of dunes.

Talbot (1985), in his discussion of Quaternary cycles of dune mobility and stabilization, argued that "dinosaurs in Mongolia were hatching and raising their young in a moist, stabilized dunefield rather than an active sea". Our observations on the clay-coated sand grains, pedogenic calcite, bioturbation, and lateral relationships between the dune and sandslide facies lead us to agree that this is the case at Ukhaa Tolgod. Although the travel literature of Central Asia and Arabia commonly cites heat, cold, and drought as causes for mass mortality, Finch et al. (1972) found no reports documenting the smothering of animals during desert dust storms and sandstorms. Although they contain abundant signs of life, the cross-stratified eolian facies at Ukhaa Tolgod (E-1 and E-2) are essentially devoid of skeletal remains. If stratal geometry and taphonomic evidence were not considered, the structureless sandstones of Facies $\mathrm{S}$ might be interpreted as eolian sediment that accumulated slowly enough for bioturbation to keep pace with deposition. However, it is unlikely that small, delicate mammal and lizard fossils would have been preserved essentially intact after extensive bioturbation. The abundant articulated skeletons are, thus, clear evidence for rapid deposition. The absence of skeletons in the eolian strata that show evidence for rapid emplacement (Facies E-1) is inconsistent with the "sandstorm" hypothesis for fossilization.

Our sandslide interpretation for Facies $\mathrm{S}$ provides an alternative to the sandstorm (eolian) hypothesis for in situ burial of articulated skeletons. The high, sparsely vegetated landforms were a sediment reservoir available for episodic gravity flows capable of quickly burying intact, unscavenged skeletons and, possibly, live animals. Heavy rainfall events acted as the triggering mechanism. However, the low permeability of calcitecemented zones at shallow depth below lee slopes of dunes is the sine qua non of the lethal mass wasting.

Comments on Formational Assignment And Geologic Age: The question arises as to whether the strata at Ukhaa Tolgod are best referred to as extensions of the type Djadokhta or Barun Goyot Formation. A preliminary investigation referred the exposures at Ukhaa Tolgod to the Djadokhta Formation (Dashzeveg et al., 1995).

Such an assignment must be based primarily on lithologic criteria, with fossil content playing a subordinate role, if any (Hedburg, 1976). Gradziński et al. (1977) provided diagnoses for the Djadokhta and Barun Goyot Formations; however, they noted (Gradziński et al., 1977: 307), "No physical contact between the Djadokhta and Barun Goyot formations has yet been discovered". To our knowledge, that is, unfortunately, still the case today, making assignment of the strata at Ukhaa Tolgod more difficult.

Yet, similar to the classic Djadokhta exposures at Bayn Dzak, the sequence of strata at Ukhaa Tolgod reflects a mixture of facies E-1, $\mathrm{E}-2, \mathrm{~F}$, and $\mathrm{S}$ in the lower part of the section, with prominent beds of Facies $\mathrm{C}$ near the top (Gradziński et al., 1969, 1977; Gradziński, 1970; Dashzeveg et al., 2005). Dashzeveg et al. (2005) refer the exposures at Bayn Dzak to the Bayn Dzak Member of the Djadokhta Formation. Such a sequence has yet to be 

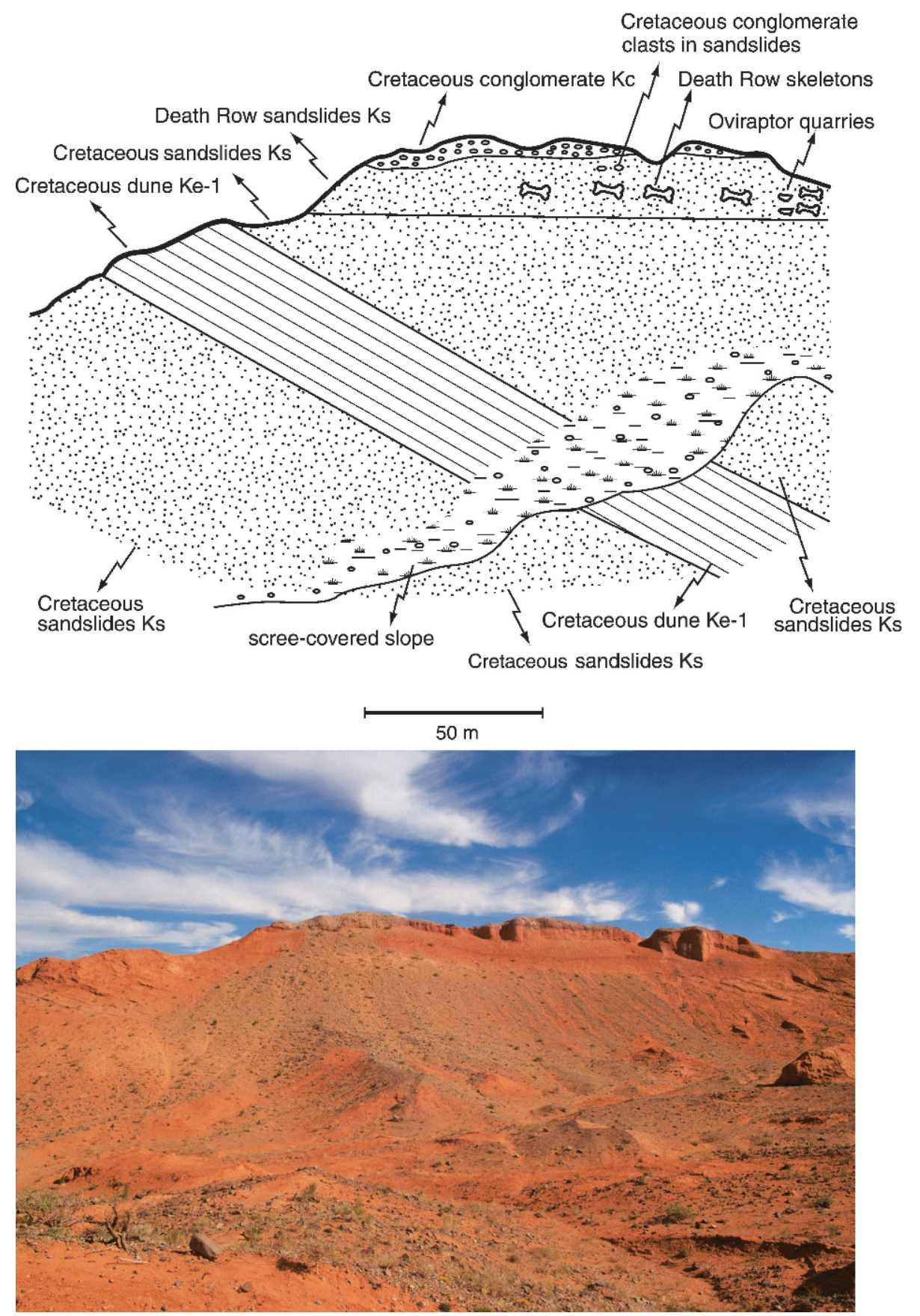

Fig. 16. Top: Schematic cross section of exposures on north side of Camel Humps Basin containing localities of Death Row and admixed sandslide and fluvial deposits. Location of site is labeled on maps 1 and 4. Bottom: Exposures on northern side of Camel Humps Basin, including Death Row, which is contained in structureless sandstone (Facies S) about 7-8 $\mathrm{m}$ below the top of the ridge. 


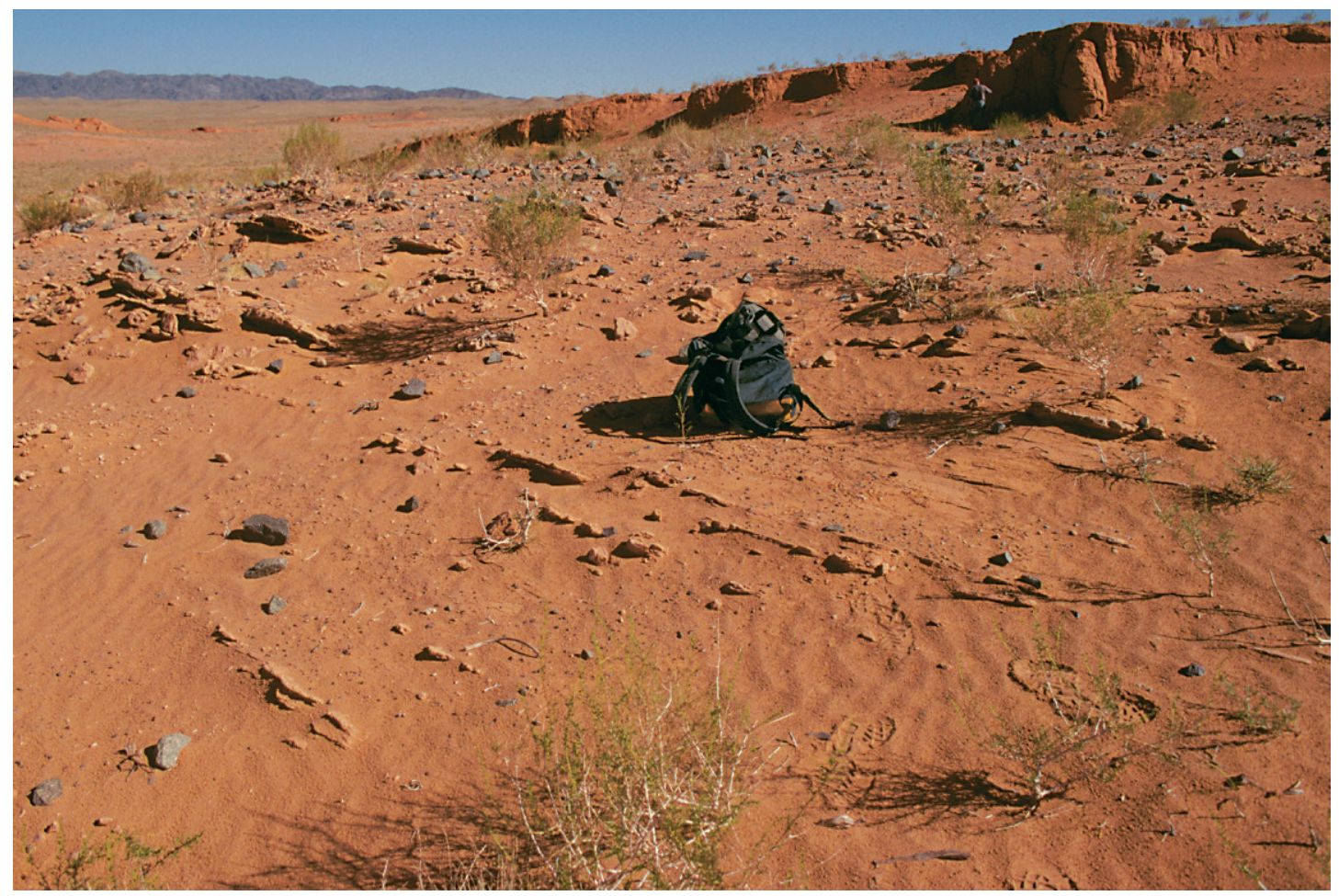

Fig. 17. View looking northeast from Xanadu Southwest showing resistant, vaguely bedded, cross-strata of Facies E-2 in foreground by pack.

recognized in classic Barun Goyot exposures at Khulsan or Khermeen Tsav (Gradziński and Jerzykiewicz, 1974a, 1974 b; Gradziński et al., 1977). Instead, as those authors state (Gradziński et al., 1977: 287), "Flat-bedded sandstones intercalated with mudstones and/ or siltstones become dominant in the uppermost part of the section". Hence, the sequence of strata at Ukhaa Tolgod conforms more closely to the sequence of the Bayn Dzak Member of the Djadokhta Formation at Bayn Dzak. Given that neither the Bayn Dzak Member nor the Djadokhta Formation has been previously recognized in the Nemegt Basin, one might question whether such a large geographic extension southward from the Ulan Nur Basin can be justified. However, correlative strata of the Djadokhta Formation have already been recognized even further to the south at Bayan Mandahu in Chinese Inner Mongolia (e.g., Jerzykiewicz et al., 1993a, 1993b). Given these points, we refer the strata at Ukhaa Tolgod to the Bayn Dzak Member of the Djadokhta Formation.
Makovicky 2007 developed "cladistic biochronologic analysis", which uses phylogenetic branching pattern to temporally order paleobiotas. This technique is based on Brook's parsimony analysis (Brooks, 1990) and allows faunas to be temporally ordered if a good fossil record is present, even if no geochronologic evidence is available. Note, however, that while this method orders different faunas it does not indicate absolute age or amount of time between faunas. Makovicky's analysis of Djadoktha localities was based on lizards, dinosaurs, mammals and turtles. He showed that using the CBA method, the Ukhaa Tolgod fauna clustered with localities classically considered to be Barungoyotian in age, younger than other classic Djadoktha localities like Bayn Dzak.

Faunas from the Djadokhta Formation have been assigned a Campanian-Early Maastrichtian age by Lillegraven and McKenna (1986) and Averianov (1997), based primarily on biochronologic interpretations. Using a line of evidence independent of biochronologic inter- 


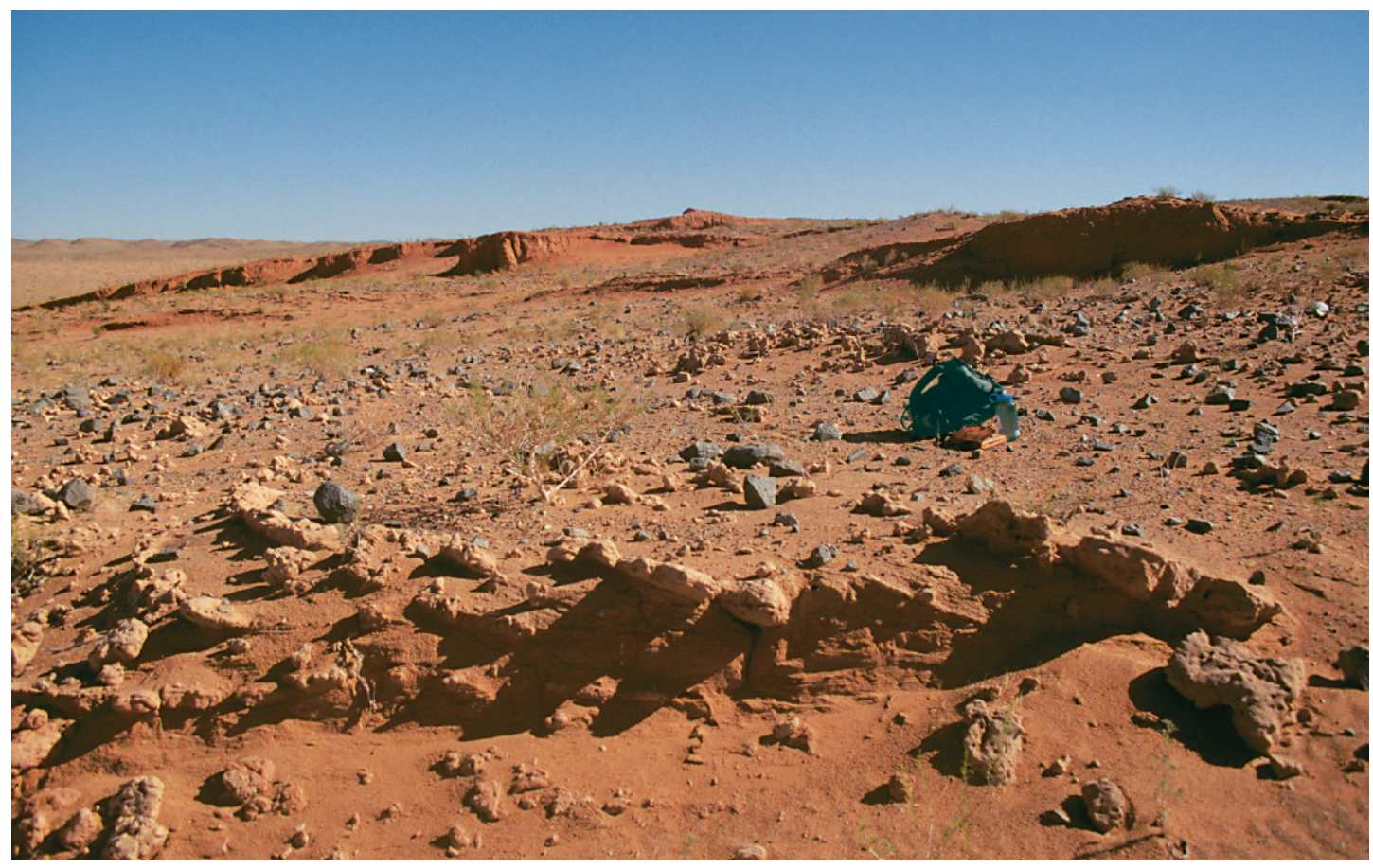

Fig. 18. View looking southeast across flats and low bluffs of Xanadu. The low ledge in the foreground is composed of structureless sandstone (Ks) that contains abundant fossils, whereas the low bluffs in the distance beyond the pack are composed of cross-stratified sandstone $(\mathrm{Ke})$.

pretations to test these assignments, Dashzeveg et al. (2005) assign a late Campanian age to the strata of the Bayn Dzak Member at Bayn Dzak based on tentative magnetostratigrapic correlations to the Geomagnetic Polarity Timescale (Gradstein et al., 1995). Further, in their analysis of the lizard faunas from the Djadokhta and Barun Goyot Formations, Gao and Norell (2000) state, "lizards provide little evidence for temporally ordering or subdividing Barun Goyot and Djadokhta localities, since 15 of the $19(78.9 \%)$ lizard species that occur at more than one locality are found in both Barun Goyot and Djadokhta localities". Based on the superpositional relationship between the Tugrugyin Member and Bayn Dzak Member proposed by Dashzeveg et al. (2005), the fauna from Tugrugyin Shireh must be somewhat younger than that from Bayn Dzak, although the extent of this age difference is presently uncertain. Regarding the mammalian faunas from Bayn Dzak, Tugrugyin Shireh, and Ukhaa Tolgod, the extensive variation in form observed in the large sample of multituberculate skulls from Ukhaa Tolgod is now being analyzed systematically. Those analytical results could well affect the current taxonomic identifications for multituberculates from all three localities. Consequently, pending further evidence and analysis, the vertebrate fauna at Ukhaa Tolgod (table 1) is thought here to reflect a Campanian age.

\section{CONCLUSIONS}

The deposits exposed in the Ukhaa Tolgod Basin represent a mosaic of previously described cross-stratified dune units, siltstone interdune deposits, and conglomeratic beds washed in from the basin margin, mixed with structureless sands interpreted here to represent a newly recognized facies of sandslides deposited at the base of the dunes (S). Vertebrates traversed the dunefield when it was active, as evidenced by the concave-up depressions interpreted to represent their tracks. However, their fossilized skeletal remains were preserved exclusively in the 

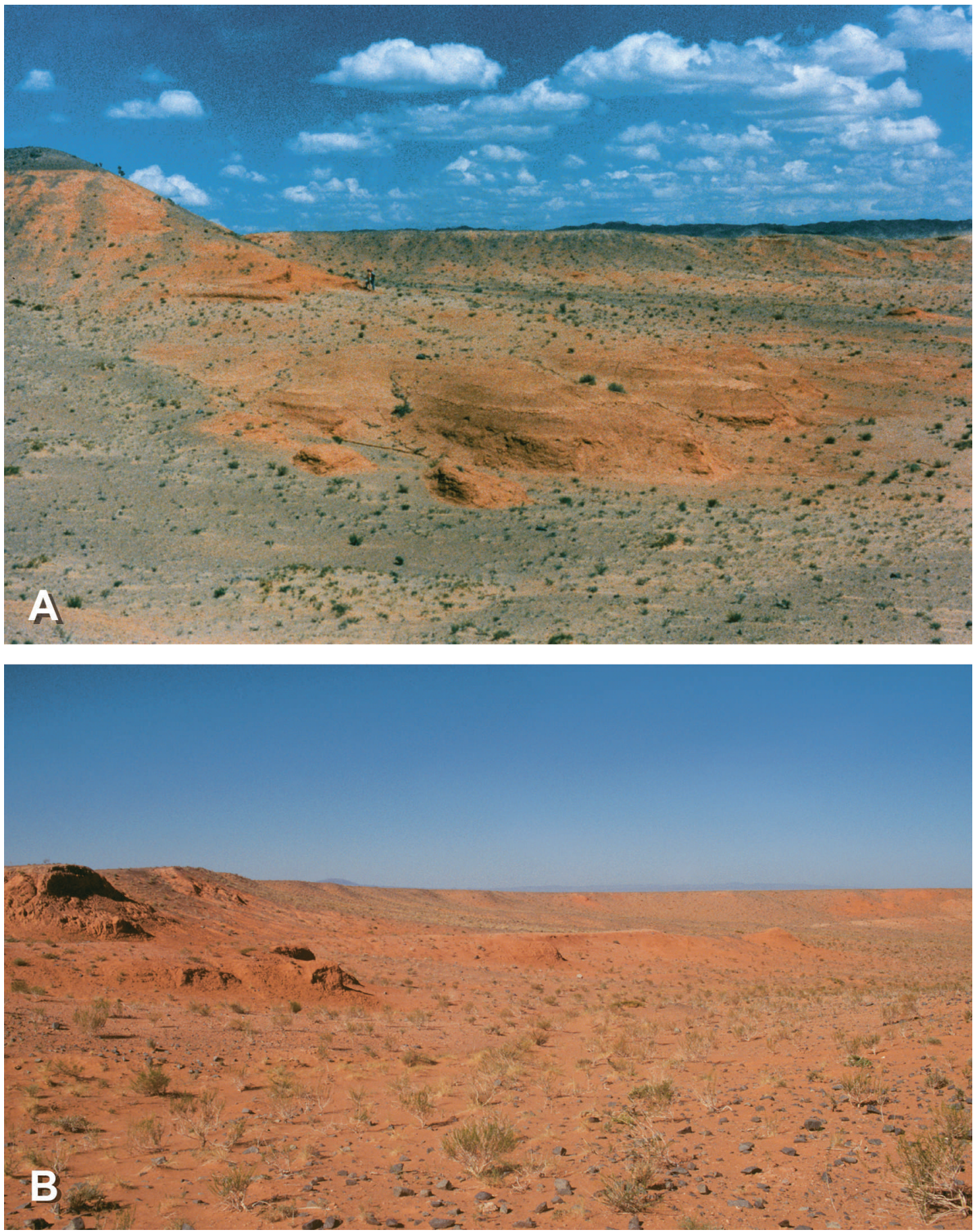

Fig. 19. A. View looking southeast showing basal ridges of siltstone (Facies $\mathrm{M}$ ) and overlying structureless sandstone (Facies S) at First Strike. B. View looking northeast between Camel Humps and First Strike showing trace of white caliche pebble layer exposed on top of low ridges (center) and flats (right) near First Strike. 

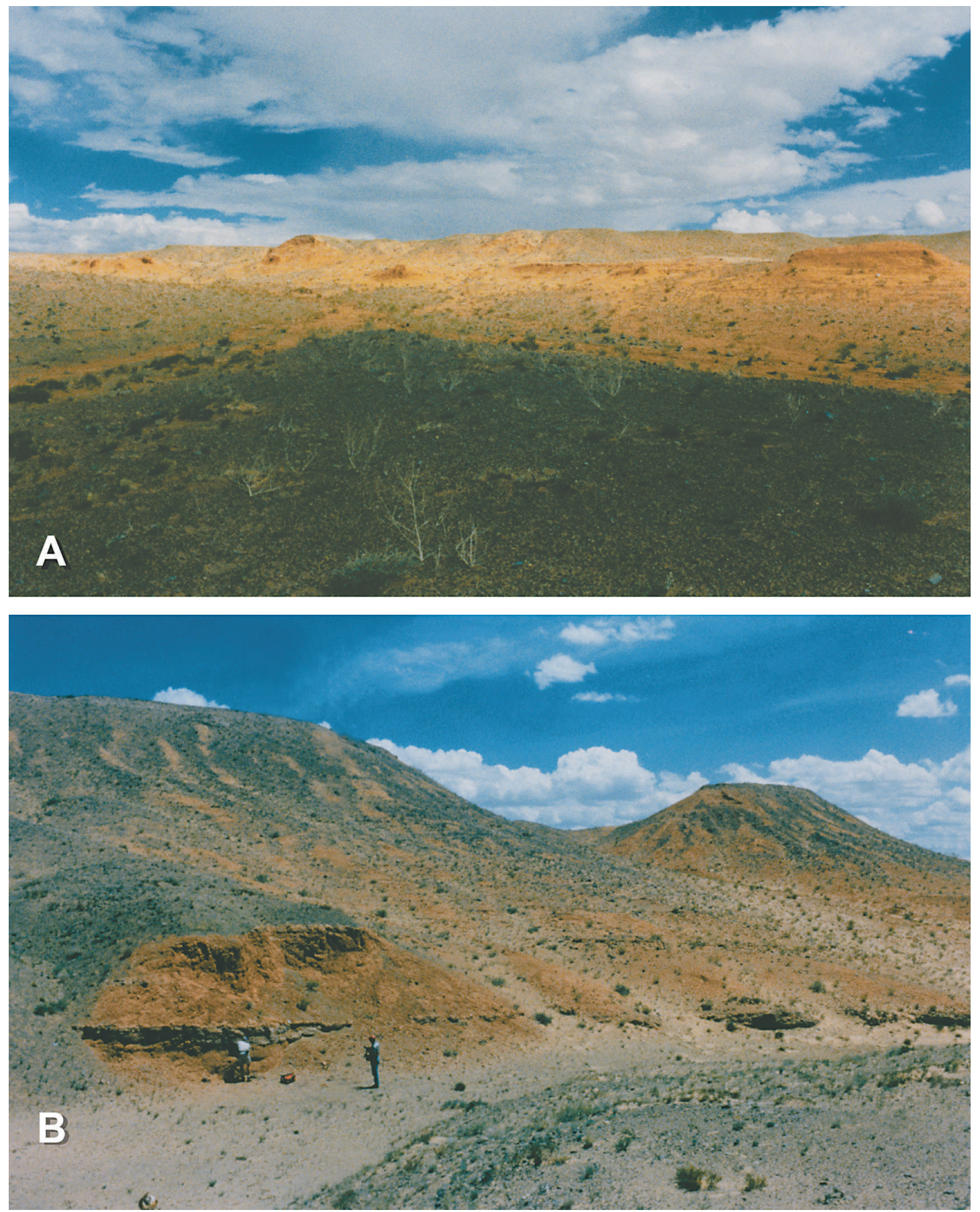

Fig. 20. A. Overview looking northeast at exposures of Zofia's Hill (right foreground) Zofia's Middle (center), and Zofia's North (left background). B. View looking east at Zofia's Middle with prominent bed of conglomerate (Facies C) exposed near the base (by crew members). 
TABLE 1

Vertebrate Faunal List for Ukhaa Tolgod

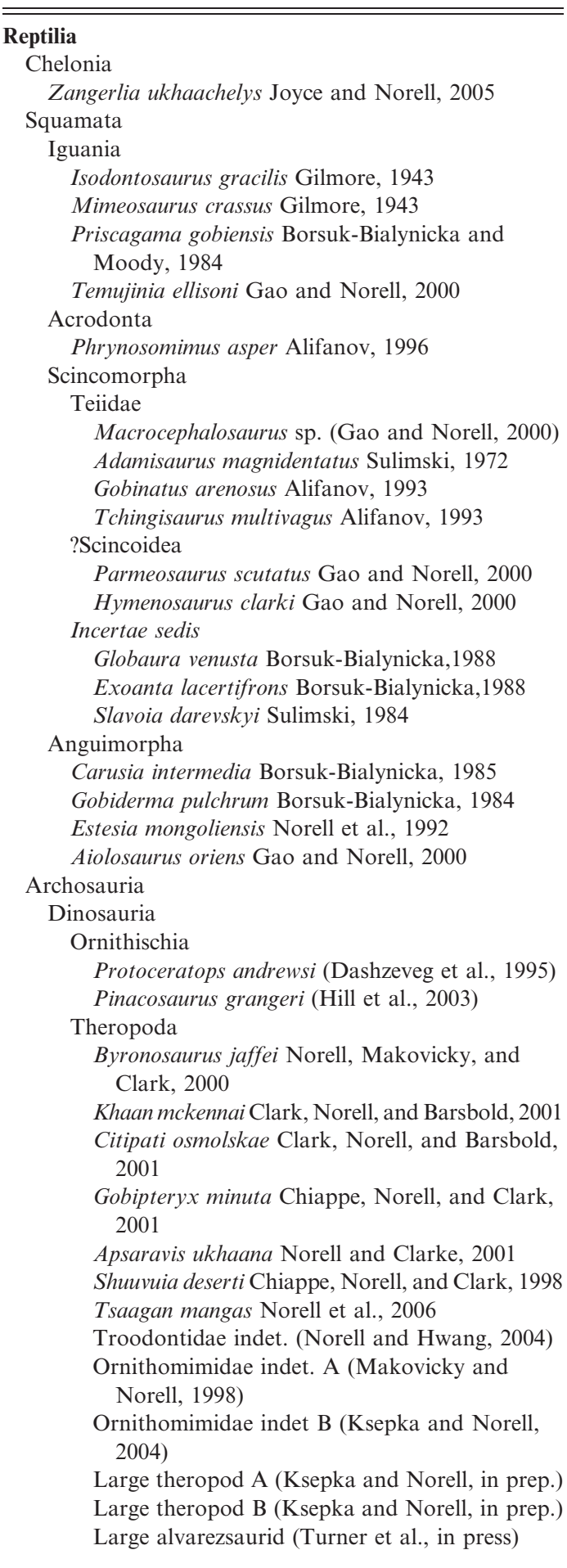

TABLE 1

Continued

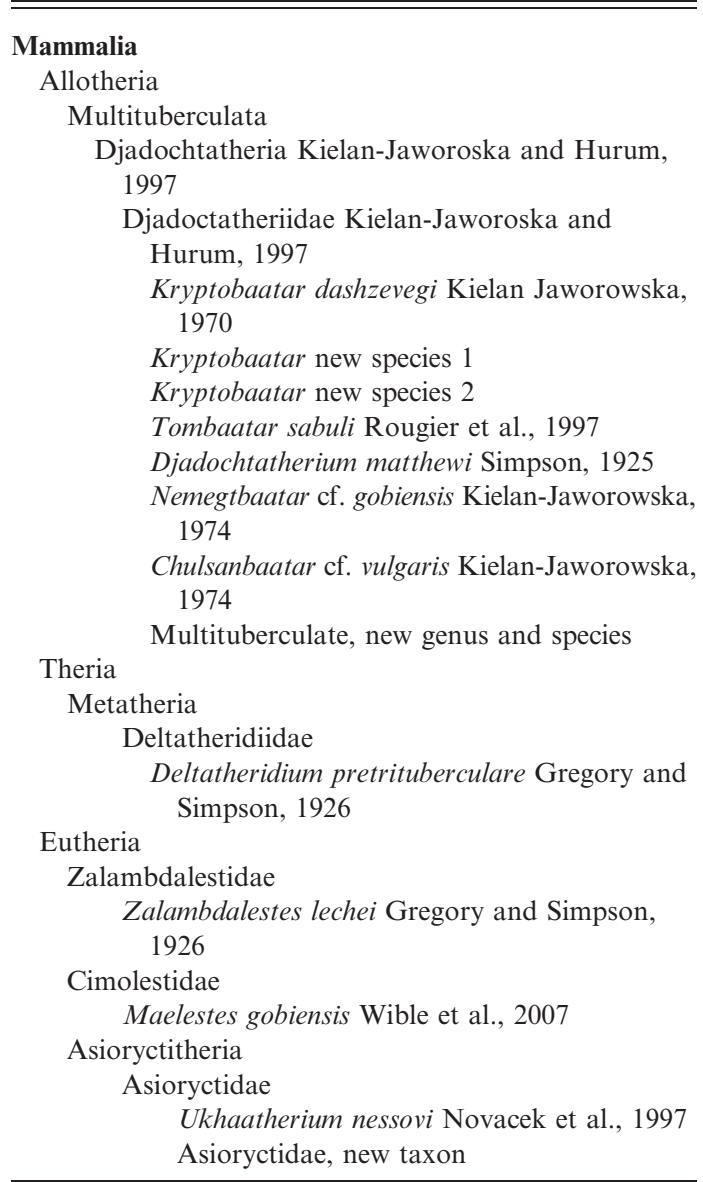

sandslide facies (including admixed fluvial deposits). Their preservation seems to be associated with the sandy mass flows that formed the fans during periods when dunes were stabilized and after pedogenic calcite had accumulated under dune slopes. Rainfall saturated the upper portion of the dunes and triggered the debris flows. The dunes were sparsely vegetated, as evidenced by the occasional zones of rhizoliths preserved in the cross-stratified sands. The distinctly crossstratified sands (E-1) accumulated during more arid periods when dunes were mobile; burrowing and calcite accumulation (Facies E2) took place when dunes were stabilized. Ephemeral small lakes or ponds occasionally occupied the interdune corridors and received silty muds and sands (Facies M). Both before and after the dunefield formed, coarse clasts 
derived from nearby topographic highs washed into the area of the dunefield from the basin margin.

Based on superpositional similarities of these facies at Ukhaa Tolgod and Bayn Dzak, the exposures at Ukhaa Tolgod are assigned to the Bayn Dzak Member of the Djadokhta Formation. At both localities, facies E-1, E-2, S, and M dominate the lower portions of the sections, with prominent beds of Facies $\mathrm{C}$ exposed near the top. Exposures of the Barun Goyot Formation at Khulsan differ substantially, with units of flat-bedded sandstone intercalated with beds of Facies M dominating the upper portion of the sequence (Gradziński et al., 1977).

The vertebrate fauna from Ukhaa Tolgod is tentatively assigned a Campanian age, based on recent biochronologic and magnetostratigraphic analyses (Lillegraven and McKenna, 1986; Averianov, 1997; Gao and Norell, 2000; Dashzeveg et al., 2005).

\section{ACKNOWLEDGMENTS}

The authors wish to thank the Mongolian Academy of Sciences, as well as the field crews from the American Museum of Natural History. We also wish to thank Zofia KielanJaworowska, Jason Lillegraven, David Eberth, Dale Russell, and one anonymous reviewer for their extensive reviews of this manuscript, without implying that they concur with all the statements and conclusions presented herein. Illustrations for both this paper and Dashzeveg et al., 2005, were compiled and drafted by Frank Ippolito, and assistance in compiling the faunal lists was generously provided by James Clark and Gao Keqin. Financial support for this study was provided by the Frick Endowment to the Division of Paleontology at the American Museum of Natural History, the InfoQuest Foundation, the Ann and Gordon Getty Foundation, and the Charlotte and Walter Kohler Charitable Trust.

\section{REFERENCES}

Ahlbrandt, T.S., and S.G. Fryberger. 1981. Sedimentary features and significance of interdune deposits. In F.G. Ethridge and R.M. Flores (editors), Recent and ancient nonmarine depositional environments: models for exploration. Society of Economic Mineralogists and Petrologists Special Publication 31: 293-314.

Alifanov, V.R. 1993. New lizards of the Macrocephalosauridae (Sauria) from the Upper Cretaceous of Mongolia, critical remarks on the systematics of the Teiidae (sensu Estes, 1983). Paleontological Journal 27: 70-90.

Alifanov, V.R. 1996. Lizards of the families Priscagamidae and Hoplocercidae (Sauria, Iguania): phylogenetic position and new representatives from the Late Cretaceous of Mongolia. Paleontological Journal 30: 466-483.

Alifanov, V.R. 2000. The fossil record of the Cretaceous lizards from Mongolia. In M.J. Benton, M.A. Shishkin, E.N. Kurochkin and D.M. Unwin (editors), The age of dinosaurs in Russia and Mongolia: 368-389. Cambridge: Cambridge University Press.

Andrews, R.C. 1932. The new conquest of Central Asia, natural history of Central Asia, I. New York: American Museum of Natural History, $687 \mathrm{pp}$.

Averianov, A.O. 1997. New Late Cretaceous mammals of southern Kazakhstan. Acta Palaeontologica Polonica 42: 243-256.

Benton, M.J. 2000. Mongolian place names and stratigraphic terms. In M.J. Benton, M.A. Shishkin, E.N. Kurochkin and D.M. Unwin (editors), The age of dinosaurs in Russia and Mongolia: xxii-xxviii. Cambridge: Cambridge University Press.

Berkey, C.P., and F.K. Morris. 1927. Geology of Central Asia, natural history of Central Asia, II. New York: American Museum of Natural History, $475 \mathrm{pp}$.

Borsuk-Bialynicka, M. 1984. Anguimorphans and related lizards from the Late Cretaceous of the Gobi Desert, Mongolia. In Z. KielanJaworowska (editor), Results of the PolishMongolian Palaeontological Expeditions. Part X. Palaeontologia Polonica 46: 5-105.

Borsuk-Bialynicka, M. 1985. Carolinidae, a new family of xenosaurid-like lizards from the Upper Cretaceous of Mongolia. Acta Palaeontologica Polonica 30: 151-176.

Borsuk-Bialynicka, M. 1988. Globaura venusta gen. et sp. n. and Eoxanta lacertifrons gen. et sp. n.non-teiid lacertoids from the Late Cretaceous of Mongolia. Acta Palaeontologica Polonica 33: 211-248.

Borsuk-Bialynicka, M. 1991a. Cretaceous lizard occurrences in Mongolia. Cretaceous Research 12: 607-608.

Borsuk-Bialynicka, M. 1991b. Questions and controversies about saurian phylogeny, Mongolian perspective. In Z. Kielan-Jaworowska, N. Heintz and H.A. Nakrem (editors), Fifth 
Symposium on Mesozoic Terrestrial Ecosystems and Biota, Oslo: 9-10.

Brooks, D.R. 1990. Parsimony analysis in historical biogeographyand coevolution- methodological and theoretical update. Systematic Zoology 39(1): 14-30.

Chiappe, L.M., M.A. Norell, and J.M. Clark. 1998. The skull of a relative of the stem-group bird Mononykus. Nature 392: 275-278.

Chiappe, L.M., M.A. Norell, and J.M. Clark. 2001. A new skull of Gobipteryx minuta (Aves: Enantiornithes) from the Cretaceous of the Gobi Desert. American Museum Novitates 3346: 1-15.

Chiappe, L.M., M.A. Norell, and J.M. Clark. 2002. The Cretaceous, short-armed Alvarezsauridae: Mononykus and its kin. In L.M. Chiappe and L.M. Witmer (editors), Mesozoic birds: 87-120. Berkeley: University of California Press.

Clark, J.M., M.A. Norell, and R. Barsbold. 2001. Two new oviraptorids (Theropoda: Oviraptorosauria) Upper Cretaceous Djadoktha Formation, Ukhaa Tolgod, Mongolia. Journal of Vertebrate Paleontology 21(2): 209-213.

Clark, J.M., M.A. Norell, and L.M. Chiappe. 1999. An oviraptorid skeleton from the Late Cretaceous of Ukhaa Tolgod, Mongolia, preserved in an avialanlike brooding position over an oviraptorid nest. American Museum Novitates 3265: 1-36.

Dashzeveg, D., L. Dingus, D.B. Loope, C.C. Swisher III, T. Dulam, and M.R. Sweeney. 2005. New stratigraphic subdivision, depositional environment and age estimate for the upper Cretaceous Djadokhta Formation, southern Ulan Nur Basin, Mongolia. American Museum Novitates 3498: 1-31.

Dashzeveg, D., M.J. Novacek, M.A. Norell, J.M. Clark, L.M. Chiappe, A. Davidson, M.C. McKenna, L. Dingus, C. Swisher, and A. Perle. 1995. Extraordinary preservation in a new vertebrate assemblage from the Late Cretaceous of Mongolia. Nature 374: 446-449.

Eberth, D.A. 1993. Depositional environments and facies transitions of dinosaur-bearing Upper Cretaceous redbeds at Bayan Mandahu (Inner Mongolia, People's Republic of China). Canadian Journal of Earth Sciences 30: 2196-2213.

Efremov, I.A. 1949. Preliminary results of the work of the first Mongolian Paleontological Expedition of the Academy of Sciences USSR, 1946. Trudy Mongolskoy Komissii AN SSSR 38: 8-27.

Efremov, I.A. 1954. Paleontological Expedition of the Mongolian People's Republic (Preliminary results of 1946,1948 and 1949 expeditions).
Trudy Mongolskoy Komissii AN SSSR 59: 3-22.

Esteban, M., and C.F. Klappa. 1983. Subaerial exposure environment. In P.A. Scholle, D.G. Bebout and C.H. Moore (editors), Carbonate depositional environments. American Association of Petroleum Geology Memoir 33: 1-54.

Fastovsky, D.E., D. Badamgarav, H. Ishimoto, M. Watabe, and D.B. Weishampel. 1997. The paleoenvironments of Tugrikin-Shireh (Gobi Desert, Mongolia) and aspects of the taphonomy and paleoecology of Protoceratops (Dinosauria: Ornithischia). Palaios 12: 59-70.

Finch, W.I., F.C. Whitmore, and J.D. Sims. 1972. Stratigraphy, morphology, and paleoecology of a fossil peccary herd from western Kentucky. United States Geological Survey Professional Paper 790: 1-25.

Gao, K., and M.A. Norell. 2000. Taxonomic composition and systematics of Late Cretaceous assemblages from Ukhaa Tolgod and adjacent localities, Mongolian Gobi Desert. Bulletin of the American Museum of Natural History 249: 1-118.

Gilmore, C.W. 1943. Fossil lizards of Mongolia. Bulletin of the American Museum of Natural History 81: 361-384.

Gradstein, F.M., F.P. Agterberg, J.G. Ogg, J. Hardenbol, P.V. Veen, J. Thierry, and Z. Huang. 1995. A Triassic, Jurassic and Cretaceous time scale. In W.A. Berggren, D.V. Kent and J. Hardenbol (editors), Geochronology, timescales and global stratigraphic correlation. Society of Economic Paleontologists and Mineralogists Special Publication 54: 95-126.

Gradziński, R. 1970. Sedimentation of dinosaurbearing Upper Cretaceous deposits of the Nemegt Basin, Gobi Desert. In Z. KielanJaworowska (editor), Results of the PolishMongolian Palaeontological Expeditions. Part II. Palaeontologia Polonica 21: 147-229.

Gradziński, R., and T. Jerzykiewicz. 1972. Additional geographical and geological data from the Polish-Mongolian Palaeontological Expeditions. In Z. Kielan-Jaworowska (editor), Results of the Polish-Mongolian Palaeontological Expeditions. Part IV. Palaeontologia Polonica 25: 17-30.

Gradziński, R., and T. Jerzykiewicz. 1974a. Sedimentation of the Barun Goyot Formation. In: Z. Kielan-Jaworowska (editor), Results of the Polish-Mongolian Palaeontological Expeditions. Part V. Palaeontologia Polonica 30: 111-146.

Gradziński, R., and T. Jerzykiewicz. 1974b. Dinosaur- and mammal-bearing aeolian and associated deposits of the Upper Cretaceous in 
the Gobi Desert (Mongolia). Sedimentary Geology 12: 249-278.

Gradziński, R., J. Kazimierczak, and J. Lefeld. 1969. Geographical and geological data from the Polish-Mongolian Palaeontological Expedition. In Z. Kielan-Jaworowska (editor), Results of the Polish-Mongolian Palaeontological Expeditions. Part I. Paleontologia Polonica 19: 33-82.

Gradziński, R., Z. Kielan-Jaworowska, and T. Maryańska. 1977. Upper Cretaceous Djadokhta, Barun Goyot and Nemegt Formations of Mongolia, including remarks on previous subdivisions. Acta Geologica Polonica 27: 281-318.

Graham, J. 1984. Methods of stability analysis. In D. Brunsden and D.B. Prior (editors), Slope instability: 171-215. Chichester, NY: John Wiley.

Gregory, W.K., and G.G. Simpson. 1926. Cretaceous mammal skulls from Mongolia. American Museum Novitates 225: 1-20.

Hedberg, H.D. 1976. International stratigraphic guide. New York: John Wiley, 200 pp.

Hill, R.A., L.M. Witmer, and M.A. Norell. 2003. A new specimen of Pinacosaurus grangeri (Dinosauria: Ornithischia) from the Late Cretaceous of Mongolia: ontogeny and phylogeny of ankylosaurs. American Museum Novitates 3395: 1-29.

Horovitz, I. 2000. The tarsus of Ukhaatherium nessovi (Eutheria, Mammalia) from the Late Cretaceous of Mongolia: an appraisal of the evolution of the ankle in basal therians. Journal of Vertebrate Paleontology 20: 547-560.

Hunter, R.E. 1977. Basic types of stratification in small eolian dunes. Sedimentology 24: 362-387.

Hunter, R.E. 1981. Stratification styles in eolian sandstones: some Pennsylvanian to Jurassic examples from the western interior, U.S.A. Society of Economic Paleontologists and Mineralogists Special Publication 31: 315-329.

Ishii, K., M. Watabe, S. Suzuki, S. Ishigaki, R. Barsbold, and K. Tsogtbaatar. 2000. Results of the Hayashibara Museum of Natural SciencesMongolian Academy of Sciences Mongolian Paleontological Center Joint Paleontological Expedition. Hayashibara Museum of Natural Sciences Research Bulletin 1: 1-137.

Ishii, K., M. Watabe, S. Suzuki, S. Ishigaki, R. Barsbold, and K. Tsogtbaatar. 2004. Results of the Hayashibara Museum of Natural SciencesMongolian Academy of Sciences Mongolian Paleontological Center Joint Paleontological Expedition. Hayashibara Museum of Natural Sciences Research Bulletin 2: 1-134.

Jerzykiewicz, T. 1998. Okavango Oasis, Kalahari Desert: a contemporary analogue for the Late Cretaceous vertebrate habitat of the Gobi
Basin, Mongolia. Geoscience Canada 25(1): $15-26$

Jerzykiewicz, T. 2000. Lithostratigraphy and sedimentary settings of the Cretaceous dinosaur beds of Mongolia. In M.J. Benton, M.A. Shishkin, E.N. Kurochkin and D.M. Unwin (editors), The age of dinosaurs in Russia and Mongolia: 279-296. Cambridge: Cambridge University Press.

Jerzykiewicz, T., P.J. Currie, D.A. Eberth, P.A. Johnston, E.H. Koster, and J.-J. Zheng. 1993a. Djadokhta Formation correlative strata in Chinese Inner Mongolia: an overview of the stratigraphy, sedimentary geology, and paleontology and comparisons with the type locality in the pre-Altai Gobi. Canadian Journal of Earth Science 30: 2180-2195.

Jerzykiewicz, T., E.H. Koster, and J.-J. Zengh. 1993b. Djadokhta Formation correlative strata in Chinese Inner Mongolia: an overview of the stratigraphy, sedimentary geology, and paleontology and comparisons with the type locality in the pre-Altai Gobi. Canadian Journal of Earth Sciences 30: 2180-2195.

Jerzykiewicz, T., and D.A. Russell. 1991. Later Mesozoic stratigraphy and vertebrates of the Gobi Basin. Cretaceous Research 12: 345-377.

Johnston, P.A., D.A. Eberth, and P.K. Anderson. 1996. Alleged vertebrate eggs from Upper Cretaceous redbeds, Gobi Desert, are fossil insect (Coleoptera) pupal chambers: Fictovichnus new ichnogenus. Canadian Journal of Earth Science 33: 511-525.

Joyce, W.G., and M.A. Norell. 2005. Zangerelia ukhaachelys, n. sp., a nanhsiungchelyid turtle from the Late Cretaceous of Ukhaa Tolgod, Mongolia. American Museum Novitates 3481: $1-19$.

Kielan-Jaworowska, Z. 1969. Preliminary data on the Upper Cretaceous eutherian mammals from Bayn Dzak, Gobi Desert. In Z. KielanJaworowska (editor), Results of the PolishMongolian Palaeontolgical Expeditions. Part I. Palaeontologia Polonica 19: 171-191.

Kielan-Jaworowska, Z. 1970. New Upper Cretaceous multituberculate genera from Bayn Dzak, Gobi Desert. In Z. KielanJaworowska (editor), Results of the PolishMongolian Palaeontological Expeditions. Part II. Palaeontologia Polonica 21: 35-49.

Kielan-Jaworowska, Z. 1974. Multituberculate succession in the late Cretaceous of the Gobi Desert (Mongolia). In Z. Kielan Jaworowska (editor), Results of the Polish-Mongolian Palaeontological Expeditions. Part V. Palaeontologia Polonica 30: 23-44.

Kielan-Jaworowska, Z. 1975. Evolution of the therian mammals in the Late Cretaceous of 
Asia. Part I. Deltatheridiidae. In Z. KielanJaworowska (editor), Results of the PolishMongolian Palaeontological Expeditions. Part VI. Palaeontologia Polonica 33: 103-132.

Kielan-Jaworowska, Z. 1984. Evolution of the therian mammals in the Late Cretaceous of Asia. Part VII. Synopsis. In Z. KielanJaworowska (editor), Results of the PolishMongolian Palaeontological Expeditions, Part X. Palaeontologia Polonica 46: 173-183.

Kielan-Jaworowska, Z. 1998. Humeral torsion in multituberculate mammals. Acta Palaeontologica Polonica 43: 131-134.

Kielan-Jaworowska, Z., and R. Barsbold. 1972. Narrative of the Polish-Mongolian Palaeontological Expeditions 1967-1971. In: Z. KielanJaworowska (editor), Results of the PolishMongolian Palaeontological Expeditions. Part IV. Palaeontologia Polonica 27: 5-13.

Kielan-Jaworowska, Z., R.L. Cifelli, and Z.-X. Luo. 2004. Mammals from the age of dinosaurs - origins, evolution, and structure. New York: Columbia University Press, i-xv, 630 pp.

Kielan-Jaworowska, Z., and N. Dovchin. 1969. Narrative of Polish-Mongolian Expedition 1963-1965. In Z. Kielan-Jaworowska (editor), Results of the Polish-Mongolian Palaeontological Expeditions. Part I. Palaeontologia Polonica 19: 7-32.

Kielan-Jaworowska, Z., and J.H. Hurum. 1997. Djadochtatheria - a new suborder of multituberculate mammals. Acta Palaeontologia Polonica 42: 201-242.

Kielan-Jaworowska, Z., J.H. Hurum, and D. Badamgarav. 2003. Multituberculate mammal Kryptobaatar and the distribution of mammals in the Upper Cretaceous rocks of the Gobi Desert. Acta Palaeontologica Polonica 49: 161-166.

Kielan-Jaworowska, Z., M.J. Novacek, B.A. Trofimov, and D. Dashzeveg. 2000. Mammals from the Mesozoic of Mongolia. In M.J. Benton, M.A. Shiskin, E.N. Kurochkin and D.M. Unwin (editors), The Age of Dinosaurs in Russia and Mongolia: 573-652. Cambridge, UK: Cambridge University Press.

Kocurek, G. (editor). 1988. Late Paleozoic and Mesozoic eolian deposits of the western interior of the United States. Sedimentary Geology 56: 1-413.

Kocurek, G. 1996. Desert aeolian systems. In H.G. Reading (editor), Sedimentary environments: processes, facies, and stratigraphy. 3rd ed.: 125-153. Cambridge: Cambridge University Press.

Kocurek, G., and J. Neilson. 1986. Conditions favorable for the formation of warm-climate aeolian sand sheets. Sedimentology 33: 795-816.

Ksepka, D., and M.A. Norell. 2004. Ornithomimosaur cranial material from Ukhaa Tolgod (Omnogov, Mongolia). American Museum Novitates 3448: 1-4.

Ksepka, D., and M.A. Norell. In prep.. Isolated dinosaur teeth from Ukhaa Tolgod and adjacent localities. American Museum Novitates

Kurochkin, E.N., and R. Barsbold. 2000. The Russian-Mongolian expeditions and research in vertebrate paleontology. In M.J. Benton, M.A. Shishkin, E.N. Kurochkin and D.M. Unwin (editors), The age of dinosaurs in Russia and Mongolia: 235-255. Cambridge: Cambridge University Press.

Lefeld, J. 1965. The age of mammal containing beds at Bayn Dzak, northern Gobi Desert. Bulletin de l'Académie Polonaise des Sciences C1. III. Série des Sciences Géologiques et Géographiques 13: 81-83.

Lefeld, J. 1971. Geology of the Djadokhta Formation at Bayn Dzak (Mongolia). In Z. Kielan-Jaworowska (editor), Results of the Polish-Mongolian Palaeontological Expeditions. Part III. Palaeontologia Polonica 25: 101-127.

Lewis, D.T. 1990. Origin of properties of Sand Hills soils. In A. Bleed and C. Flowerday (editors), An atlas of the Sand Hills. University of Nebraska-Lincoln, Conservation and Survey Division, Resource Atlas 5a: 57.

Lillegraven, J.A., and M.C. McKenna. 1986. Fossil mammals from the "Mesaverde" Formation / Late "Cretaceous North American LandMammal Ages". American Museum Novitates 2840: 1-68.

Lockley, M.G., and D.D. Gillette. 1989. Dinosaur tracks and traces: an overview. In D.D. Gillette and M.G. Lockley (editors), Dinosaur tracks and traces: 3-10. London: Cambridge University Press.

Loope, D.B. 1988. Rhizoliths in ancient eolianites. In G. Kocurek (editor), Late Paleozoic and Mesozoic eolian deposits of the western interior of the United States. Sedimentary Geology 56: 301-314.

Loope, D.B. 2006. Dry-sand tracks in dinosaurtriggered eolian grainflows. Palaios 21: 132142.

Loope, D.B., and L. Dingus. 1999. Mud-filled Ophiomorpha from the Upper Cretaceous continental redbeds of southern Mongolia: an ichnologic clue to the origin of detrital grain coatings. Palaios 14: 451-458.

Loope, D.B., L. Dingus, C.C. Swisher III, and C. Minjin. 1998. Life and death in a late 
Cretaceous dune field, Nemegt basin, Mongolia. Geology 26: 27-30.

Loope, D.B., J.A. Mason, and L. Dingus. 1999. Lethal sandslides from eolian dunes. Journal of Geology 107: 707-713.

Magdefrau, K. 1956. Paleobiologie der Pflanzen. Jena: Fischer, 443 pp.

Makovicky, P.J. 2007. Telling time from fossils: a phylogeny-based approach to chronological ordering of paleobiotas. Cladistics 23(1): 1-22.

Makovicky, P.J., and M.A. Norell. 1998. A partial ornithomimid braincase from Ukhaa Tolgod (Upper Cretaceous, Mongolia). American Museum Novitates 3247: 1-16.

Maleev, E.A. 1952. A new family of armoured dinosaurs from the Upper Cretaceous deposits. Doklady Akademii Nauk SSSR 87: 131-134.

Maleev, E.A. 1954. Armoured dinosaurs from the Upper Cretaceous of Mongolia (the Syrmosauridae Family). Trudy Paleontologicheskogo Instituta Akademii Nauk SSSR 48: 142-170.

Maryańska, T. 1971. New data of the skull of Pinacosaurus grangeri (Ankylosauria). In Z. Kielan-Jaworowska (editor), Results of the Polish-Mongolian Palaeontological Expeditions. Part III. Palaeontologia Polonica 25: 45-53.

Maryańska, T., and H. Osmólska. 1975. Protoceartopsidae (Dinosauria) from Asia. In $\mathrm{Z}$. Kielan-Jaworowska (editor), Results of the Polish-Mongolian Palaeontological Expeditions. Part VI. Palaeontologia Polonica 33: 133-181.

Morris, F.K. 1936. Central Asia in Cretaceous time. Geological Society of America Bulletin 47: 1477-1534.

Norell, M.A., and J.A. Clarke. 2001. Fossil that fills a critical gap in avian evolution. Nature 409: 181-184.

Norell, M.A., J.M. Clark, and D. Dashzeveg. 1995. A nesting dinosaur. Nature 378: 774-776.

Norell, M.A., J.M. Clark, D. Dashzeveg, R. Barsbold, L.M. Chiappe, A.R. Davidson, M.C. McKenna, A. Perle, and M.J. Novacek. 1994. A theropod dinosaur embryo and the affinities of the Flaming Cliffs dinosaur eggs. Science 226: 779-782.

Norell, M.A., J.M. Clark, A.H. Turner, P.J. Makovicky, R. Barsbold, and T. Rowe. 2006. A new dromaeosaurid from Ukhaa Tolgod (Ömnögov, Mongolia). Novitates 3545: 1-51.

Norell, M.A., and S. Hwang. 2004. A troodontid dinosaur from Ukhaa Tolgod (Late Cretaceous, Mongolia). American Museum Novitates 3446: 1-9.

Norell, M.A., P. Makovicky, and J.M. Clark. 2000. A new troodontid from Ukhaa Tolgod, Late Cretaceous, Mongolia. Journal of Vertebrate
Paleontology Rapid Communication 20(1): 7-11.

Norell, M.A., M.C. McKenna, and M.J. Novacek. 1992. Estesia mongoliensis, a new fossil varanoid from the Late Cretaceous Barun Goyot Formation of Mongolia. American Museum Novitates 3045: 1-24.

Novacek, M.J., G.W. Rougier, J.R. Wible, M.C. McKenna, D. Dashzeveg, and I. Horovitz. 1997. Epipubic bones in eutherian mammals from the Late Cretaceous of Mongolia. Nature 389: 483-486.

Osborn, H.F. 1924. Three new Theropoda, Protoceratops zone, central Mongolia. American Museum Novitates 144: 1-12.

Osmólska, H. 1972. Preliminary note on a crocodilian from the Upper Cretaceous of Mongolia. In Z. Kielan-Jaworowska (editor), Results of the Polish-Mongolian Palaeontological Expeditions. Part III. Palaeontologia Polonica 27: 43-47.

Osmólska, H. 1976. New light on the skull anatomy and systematic position of Oviraptor. Nature 262: 683-684.

Osmólska, H. 1980. The Late Cretaceous vertebrate assemblages of the Gobi Desert, Mongolia. Memoirs de la Societé Geologique de France 139: $145-150$.

Osmólska, H. 1993. Were the Mongolian "fighting dinosaurs" really fighting? Review de Paléobiologie Special Volume 7: 161-162.

Rougier, G.W., M.J. Novacek, and D. Dashzeveg. 1997. A new multituberculate from the Late Cretaceous locality Ukhaa Tolgod, Mongolia: considerations on multituberculate relationships. American Museum Novitates 3193: 1-26.

Rougier, G.W., J.R. Wible, and M.J. Novacek. 1996. Middle-ear ossicles of the multituberculate Kryptobaatar from the Mongolian Late Cretaceous: implication for mammaliamorph relationships and the evolution of the auditory apparatus. American Museum Novitates 3187: $1-45$.

Rougier, G.W., J.R. Wible, and M.J. Novacek. 1998. Implications of Deltatheridium specimens for early marsupial history. Nature 396: 459-463.

Schweitzer, M.H., J.A. Watt, R. Avci, L. Knapp, L. Chiappe, M. Norell, and M. Marshall. 1999. Beta-keratin specific immunological reactivity in feather-like structures of the Cretaceous alvarezsaurid, Shuvuia deserti. Journal of Experimental Zoology (Molecular Development and Evolution) 285: 146-157.

Shuvalov, V.F. 2000. The Cretaceous stratigraphy and palaeobiogeography of Mongolia. In M.J. Benton, M.A. Shishkin, E.N. Kurochkin and D.M. Unwin (editors), The age of dinosaurs in 
Russia and Mongolia: 256-278. Cambridge: Cambridge University Press.

Simpson, G.G. 1925. A Mesozoic mammal skull from Mongolia. American Museum Novitates 201: 1-11.

Sulimski, A. 1972. Adamisaurus magnidentatus n. gen., n. sp. (Sauria) from the Upper Cretaceous of Mongolia. Palaeontologica Polonica 27: 33-40.

Sulimski, A. 1975. Macrocephalosauridae and Polyglyphanodontidae (Sauria) from the Late Cretaceous of Mongolia. In Z. KielanJaworowska (editor), Results of the PolishMongolian Palaeontological Expeditions. Part IV. Palaeontologica Polonica 33: 25-102.

Sulimski, A. 1984. A new Cretaceous scincomorph lizard from Mongolia. Palaeontologica Polonica 46: 143-155.

Suzuki, S., L.M. Chiappe, G. Dyke, W. Watabe, R. Barsbold, and K. Tsogtbaatar. 2001. A new specimen of Shuvuuia deserti from the Late Cretaceous Djadokhta Formation of Mongolia. Abstract Journal of Vertebrate Paleontology 21(3): 107A.

Svendsen, J., H. Stollhofen, C.B.E. Krapf, and I.G. Stanistreet. 2003. Mass and hyperconcentrated flow deposits record dune damming and catastrophic breakthrough of ephemeral rivers, Skeleton Coast Erg, Namibia. Sedimentary Geology 160(1-3): 7-31.

Sweeney, M.R., and D.B. Loope. 2001. Dunesourced alluvial fans of the Nebraska Sand Hills. Geomorphology 38: 31-46.

Talbot, M.R. 1985. Major bounding surfaces in eolian sand dunes - a climatic model. Sedimentology 32: 257-265.

Talbot, M.R., and M.A.J. Williams. 1978. Erosion of fixed dunes in the Sahel, central Niger. Earth Surface Processes 3: 107-113.

Talbot, M.R., and M.A.J. Williams. 1979. Cyclic alluvial fan sedimentation on the flanks of fixed dunes, Janjari, central Niger. Catena 6: 43-62.
Turner, A.H., S.J. Nesbitt, and M.A. Narell. In press. A large alvarezsaurid from the Late Cretaceous of Mongolia. American Museum Novitates.

Tverdochelebov, V.P., and Y.I. Tsybin. 1974. Genesis of the Upper Cretaceous sediments containing dinosaur remains at Tugrikin-Us and Alag Taag localities. In N.N. Krarmarenko, B. Luvsandansan, Y.I. Voronin, R. Barsbold, A.K. Rozhdestvensky, B.A. Trofimov and Y. Reshetov (editors), Mongolian Paleontological Expeditions Transactions 1: 314-319.

Wible, J.R., M.J. Novacek, and G.W. Rougier. 2004. New data on the skull and dentition in the Mongolian Late Cretaceous eutherian mammal Zalambdalestes. Bulletin of the American Museum of Natural History 281: 1-144.

Wible, J.R., and G.W. Rougier. 2000. The cranial anatomy of Kryptobaatar dashzevegi (Mammalia, Multituberculata), and its bearing on the evolution of mammalian characters. Bulletin of the American Museum of Natural History 247: 1-124.

Wible, J.R., G.W. Rougier, and M.T. Novacek. 2007. Cretaceous eutherians and Laurasian origin for placental mammals near the $\mathrm{K} / \mathrm{T}$ boundary. Nature 447: 1003-1006.

Wilson, M.D. 1992. Inherited grain-rimming clays in sandstones from eolian and shelf environments: their origin and control on reservoir properties. In D.W. Houseknecht and E.D. Pittman (editors), Society of Economic Paleontologists and Mineralogists Special Publication 47: 209-225.

Yang, X., T. Liu, and H. Xiao. 2003. Evolution of megadunes and lakes in the Badain Jaran Desert, Inner Mongolia, China during the last 31,000 years. Quaternary International 104: $99-112$.

Complete lists of all issues of the Novitates and the Bulletin are available at World Wide Web site http://library.amnh.org/pubs. Inquire about ordering printed copies via e-mail from scipubs@amnh.org or via standard mail from: American Museum of Natural History, Library-Scientific Publications, Central Park West at 79th St., New York, NY 10024. TEL: (212) 769-5545. FAX: (212) 769-5009. 